\title{
Response of drainage systems to Neogene evolution of the Jura fold-thrust belt and Upper Rhine Graben
}

\author{
Peter A. Ziegler* \& Marielle Fraefel
}

Key words: Neotectonics, Northern Switzerland, Upper Rhine Graben, Jura Mountains

\begin{abstract}
The eastern Jura Mountains consist of the Jura fold-thrust belt and the autochthonous Tabular Jura and Vesoul-Montbéliard Plateau. They are drained by the river Rhine, which flows into the North Sea, and the river Doubs, which flows into the Mediterranean. The internal drainage systems of the Jura fold-thrust belt consist of rivers flowing in synclinal valleys that are linked by river segments cutting orthogonally through anticlines. The latter appear to employ parts of the antecedent Jura Nagelfluh drainage system that had developed in response to Late Burdigalian uplift of the VosgesBack Forest Arch, prior to Late Miocene-Pliocene deformation of the Jura fold-thrust belt.

The following stages are recognized in the evolution of the Jura Mountain drainage systems: 1) middle to late Tortonian (10-7.2 Ma) folding-related overpowering and partial reversal of the south-directed Jura Nagelfluh drainage system, 2) Messinian to early Pliocene (7.2-4.2 Ma) Aare-Danube and protoDoubs stage, 3) early to middle Pliocene (4.2-2.9 Ma) Aare-Doubs stage, 4)
\end{abstract}

late Pliocene to early Quaternary (2.9-1.7 Ma) Aare-Rhine and Doubs stage and 5) Quaternary (1.7-0 Ma) Alpine-Rhine and Doubs stage.

Development of the thin-skinned Jura fold-thrust belt controlled the first three stages of this drainage system evolution, whilst the last two stages were essentially governed by the subsidence of the Upper Rhine Graben, which resumed during the late Pliocene. Late Pliocene and Quaternary deep incision of the Aare-Rhine/Alpine-Rhine and its tributaries in the Jura Mountains and Black Forest is mainly attributed to lowering of the erosional base level in the continuously subsiding Upper Rhine Graben. Incision of the Doubs and Dessoubre canyons reflects uplift of the Franches-Montagnes and Franche-Comté in response to thick-skinned deformation of the Jura fold-thrust belt, which had commenced around $3 \mathrm{Ma}$.

Geodetic data indicate that uplift of the Jura Mountains, relative to the Tabular Jura, presently continues at very low strain rates whilst the Upper Rhine Graben subsides very slowly and the Black Forest is relatively stable.

\section{Introduction}

The Jura fold-thrust belt (JFTB), forming the core of the Jura Mountains, is the youngest and most external element of the Central Alpine orogenic system. It has accounted for up to $30 \mathrm{~km}$ of essentially thin-skinned shortening since late Miocene times (Laubscher 1961, 1992; Philippe et al. 1996; Affolter $\&$ Gratier 2004) and is still seismotectonically active (Becker 2000; Lacombe \& Mouthereau 2002; Edel et al.2006). The JFTB is flanked to the SE by the flexural Swiss Molasse foreland basin of the Alps whilst its most external elements encroach on the Bresse and Upper Rhine grabens (Fig. 1; Chauve et al. 1980; Dèzes et al. 2004).

Evolution of the JFTB combined with the development of the Upper Rhine Graben (URG) and the Bresse Graben, exerted strong control on the location of the repeatedly shifting watersheds between the rivers Danube, Doubs and Rhine, which flow into the Black Sea, the Mediterranean and the
North Sea, respectively. Numerous studies have addressed the evolution of the headwaters of these major drainage systems and the underlying tectonic processes (Liniger 1966, 1967; Petit et al. 1996; Hofmann 1996; Villinger 1998; Kuhlemann \& Kempf 2002; Müller et al. 2002; Berger et al. 2005a; Ziegler \& Dèzes 2007), or have analyzed neotectonic deformation controlling drainage pattern changes at the boundary between the Jura Mountains and the URG (Giamboni et al. 2004a, b; Braillard 2006). However, only few studies have addressed the development of drainage systems within the JFTB (Heim 1919; Liniger 1953, 1966; Laubscher 1967).

In an effort to further constrain the evolution of the JFTB and its drainage systems, this paper builds on a literature review, including the pioneering work of Liniger $(1953,1966,1967)$ and Laubscher (1981, 1986, 1992), and presents a morphotectonic analysis of the drainage system. In particular, we studied the distribution of water and wind gaps (Fig. 2), considered as vestiges of antecedent rivers, and classified the different river seg-

Geological-Palaeontological Institute, University of Basel, Bernoullistr. 32, 4056 Basel, Switzerland.

*Corresponding author: P.A. Ziegler. E-mail paziegler@magnet.ch 


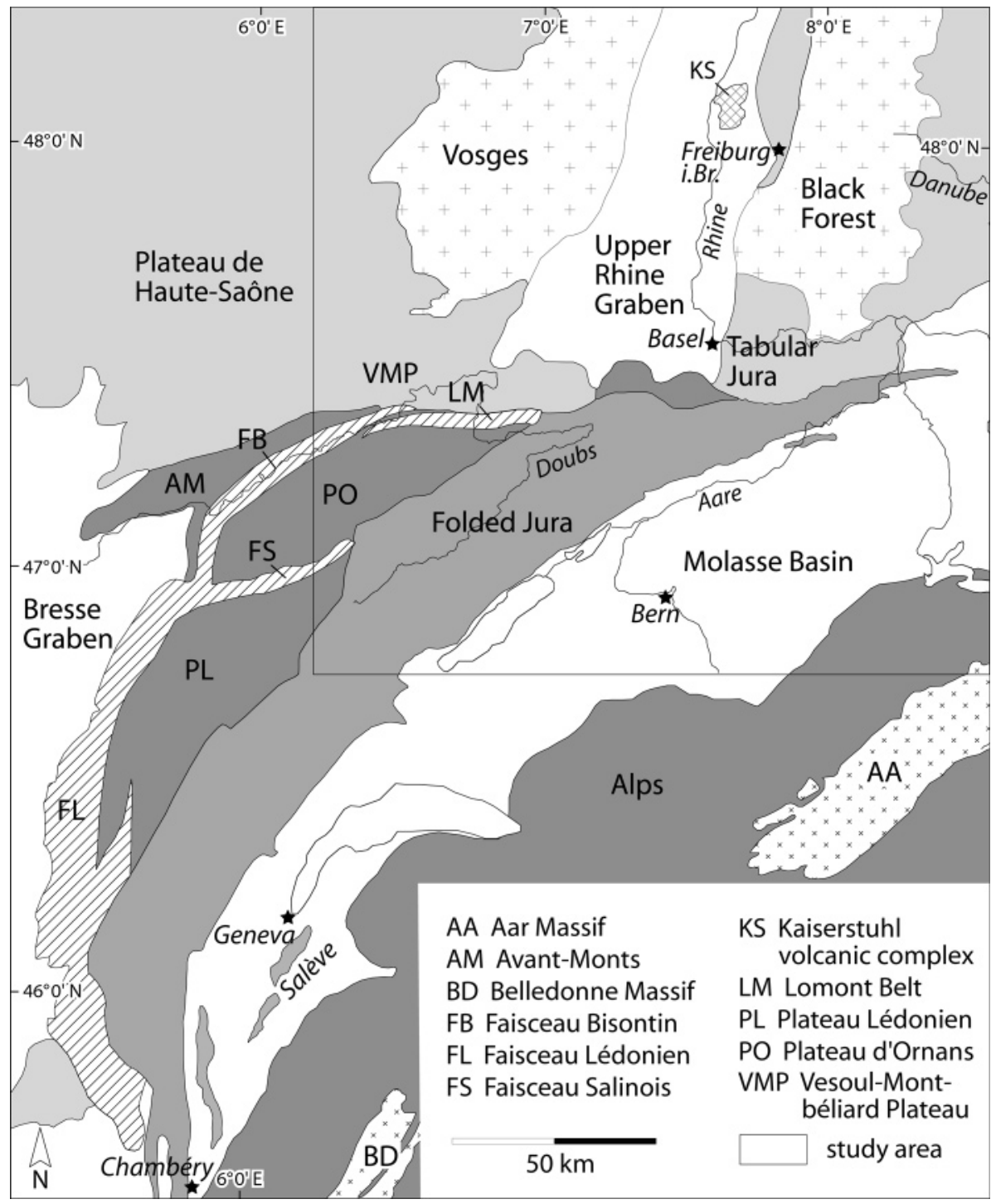

Fig. 1. Tectonic map of NW Switzerland and adjacent areas (after Ustaszewski (2004) and Chauve et al. (1980)) ments, according to their history (Fig. 3). In this context it is important to note that the pre-orogenic sedimentary record of the JFTB and its surroundings ends in Serravallian to early Tortonian times. On the other hand, its late syn-deformational sedimentary record is restricted to its northern deformation front where it commences in the late Early Pliocene (Berger et al.2005a, b). As sediments of mid-Tortonian to mid-Quaternary age are missing within the JFTB, we had to use geomorphologic criteria to further constrain its structural evolution and the development of its drainage systems. In addition, we compared indications for neotectonic activity with the results of geodetic surveys.

\section{Geological and topographic setting of the area addressed}

The main morpho-tectonic units of the Eastern Jura Mountains and their French and German foreland comprise the JFTB, which was activated during the Late Miocene, the Tabular Jura on the southern slopes of Black Forest basement arch, the Upper Rhine Graben (URG) into which the Mulhouse High projects, and on the southern slopes of the Vosges basement arch the Vesoul-Montbéliard Plateau, which grades NW-ward into the Plateau de Haute-Saône (Figs. 1 and 2). The JFTB and the undeformed Tabular Jura underlie the high topography of the Eastern Jura Mountains. The width of the essentially thinskinned JFTB decreases from $60 \mathrm{~km}$ in its western parts to zero at its eastern termination. In its western, widest parts the JFTB accounts for $25-30 \mathrm{~km}$ shortening. This value decreases eastward to $13 \mathrm{~km}$ and $7 \mathrm{~km}$ in the Delémont and Aarau transects, respectively, and to $1 \mathrm{~km}$ in the Lägern anticline (Philippe et al. 1996; Affolter \& Gratier 2004).

East of the city of Olten, the JFTB consists of a 5-8 km wide stack of thrust sheets and thrusted anticlines, tapering to zero at the eastern end of the Lägern anticline, and attains eleva-

58 P.A. Ziegler \& M. Fraefel 


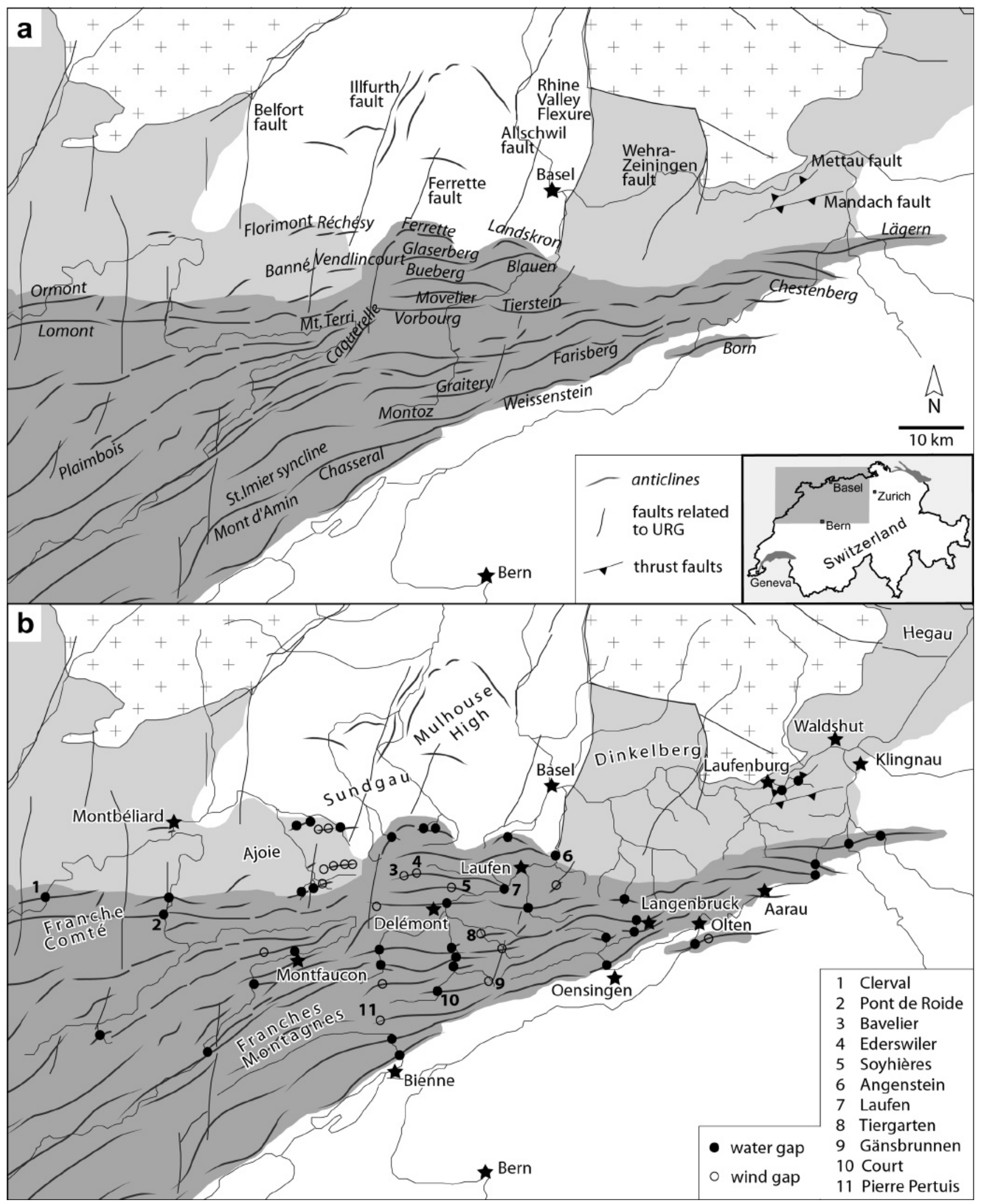

Fig. 2 a) Main tectonic elements of the study area. Crosses: outcropping basement, light grey:Tabular Jura and equivalents, dark grey: Jura fold-thrust belt, white: Cenozoic sedimentary basins. b) Prominent water and wind gaps of the study area. Same legend as $2 \mathrm{a}$. 


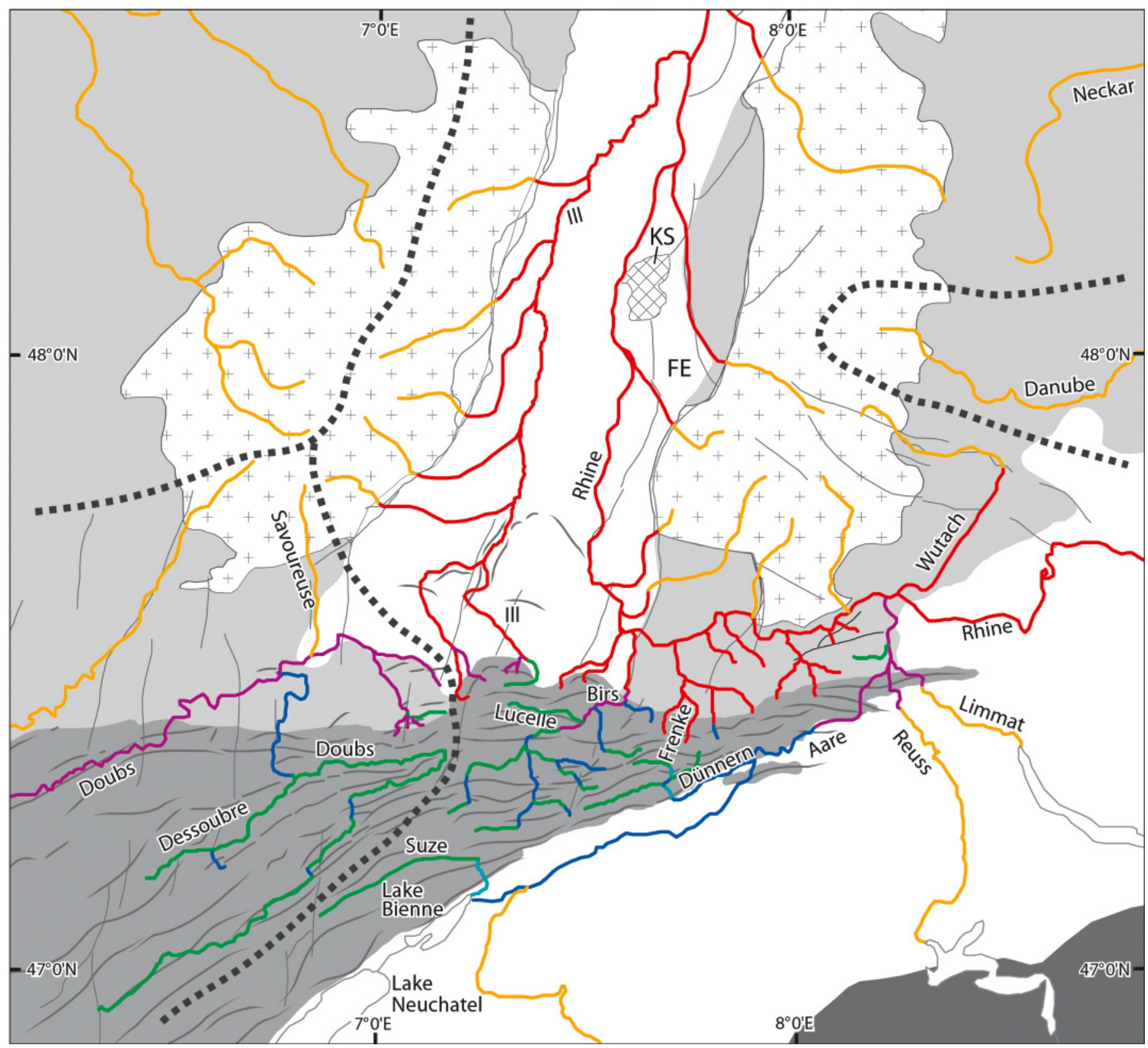

Fig. 3. Modern drainage system of the study area. Dashed lines: drainage divides. Yellow: consequent rivers related to Burdigalian uplift of Vosges-Black Forest Arch and to Alpine fans in the Molasse Basin. Rivers related to Jura folding and uplift of the Molasse Basin: subsequent (green), resequent (light blue), obsequent (dark blue), antecedent to late Jura folding (purple). Insequent rivers related to Pliocene-Quaternary subsidence of the URG (red). Abbreviations: FE Freiburg Embayment, KS Kaiserstuhl volcanic complex. For discussion see sections 4 to 8.

tions of up to $950 \mathrm{~m}$ (Fig. 2). West of Olten, the JFTB broadens to $38 \mathrm{~km}$, advances to the southern margin of the URG and is dominated by flexural-slip and thrust-faulted anticlines and broad synclines. Synclinal valleys and anticlinal ridges dominate the morphology of this province. Ridges attain elevations of up to $1300 \mathrm{~m}$ along the southern, internal margin of this province, and decrease in its northern, external parts to $800 \mathrm{~m}$ and less. This valley-and-ridge province grades westward into the undulating and gently north-sloping up to $1000 \mathrm{~m}$ high plateau of the Franches-Montagnes and Franche-Comté. This plateau is flanked to the south by the deep, synclinal St. Imier valley and the $1500 \mathrm{~m}$ high Mont d'Amin-Chasseral anticline, and to the north by the frontal Lomont and Ormont anticlines, thus accounting for a total fold-belt width of $60 \mathrm{~km}$. Main topographic features of the Franches-Montagnes and Franche-Comté are the deeply incised canyons of the rivers Doubs and Dessoubre (Fig. 3). 
In the foreland of the JFTB, to the east of Basel, monoclinally south-dipping Jurassic and Triassic sediments underlie the Tabular Jura. These are progressively eroded as they rise towards the Black Forest in which the crystalline basement is exposed. The western part of this monocline is transected by an array of mainly NNE-SSW striking normal faults that form part of the URG extensional system, whereas its eastern part is disrupted by the Mandach and Mettau thrusts (Müller et al. 2002; Laubscher 2003; Diebold et al. 2006). Similar to the Tabular Jura, the rather low lying Vesoul-Montbéliard Plateau, which flanks the Vosges to the south, is also underlain by gently south-dipping Triassic and Jurassic sediments transected by N-S to NNE-SSW striking normal faults. The URG consists of several rotational fault blocks that are delimited by NNESSW striking, west-dipping normal faults, such as the Allschwil, Ferrette and Illfurth faults (Ustaszewski 2004; Giamboni et al. 2004a; Hinsken et al. 2007). The Rhine Valley Flexure marks the eastern margin of the morphologically expressed URG and bounds the Tabular Jura to the west (Fig. 2).

The evolution of these tectonic elements had a strong bearing on the development of the drainage systems in the study area. In the following section we address the configuration of the present-day drainage systems of the Jura Mountains before discussing their step-wise evolution in sections 4 to 8 .

\section{Morphotectonic analysis of the modern drainage systems of the Jura Mountains}

The modern drainage systems of the Eastern Jura Mountains consist of (i) rivers draining southward into the river Aare, which flows NE along the southern margin of the Jura Mountains and joins the Rhine near Waldshut, (ii) rivers flowing north into the Rhine, which debouches into the North Sea, and (iii) the river Doubs, which flows into the Saône and ultimately joins the river Rhône, which flows into the western Mediterranean (Fig. 3).

A large number of tributaries to these rivers, as well as the Aare and Doubs rivers themselves, cut more or less perpendicularly through anticlines and in some cases through thrust-controlled structures. We systematically mapped these breaches and assigned them to water gaps, if a major river occupies the gap today, or to wind gaps, if a well developed breach is not occupied by a significant river. These gaps (Klusen) are interpreted as evidence of antecedent river courses that predate development of the JFTB.

The distribution of these features is summarized in Figure 2 b. Important water gaps occur particularly in the valleyand-ridge province of the JFTB, which is characterized by a trellis-type drainage pattern consisting of synclinal river valleys linked by water gaps. Interestingly, the external Glaserberg and Blauen Anticlines of the valley-and-ridge province are not cut by wind or water gaps, whilst the frontal Florimont, Réchesy, Banné, Vendlincourt, Ferrette and Landskron anticlines are breached by gaps related to northward flowing rivers. The rivers Doubs and Dessoubre of the Franches-Montagnes and
Franche-Comté are prominent examples of entrenched meandering streams that wind through synclinal valleys and a number of water gaps.

In the Tabular Jura, a dendritic drainage pattern dominates. However, some of the long, north-directed valleys of Rhine tributaries (e.g. Frenke) are aligned with NNE-SSW striking Rhine Graben-related faults. In the easternmost Jura Mountains, the external Mettau thrust is cut by water gaps whilst the Mandach thrust element to the south forms a prominent local drainage divide.

Based on the distribution of water and wind gaps, and in the context of the tectonic evolution of the study area, we have classified the rivers of the Jura Mountain drainage systems (Fig. 3), according to their history, into different categories, applying the classification schemes of Skinner and Porter (1995) and Twidale (2004). Accordingly, we assigned the rivers or river segments of the study area to one of the following groups:

Consequent: Rivers following the slope of a newly uplifted land mass

Insequent: Dendritic pattern of tributaries developing by random headward erosion little influenced by the structure and lithology of incised strata

Antecedent: Rivers maintaining their initial course across a land mass or fold that is uplifted across their path, rather than flowing around it

Subsequent: Rivers flowing in structurally controlled valleys that developed in response to folding of an area initially drained by consequent rivers

Resequent: Rivers flowing after folding of an area in the same direction as the initial consequent drainage system, employing segments of antecedent rivers

Obsequent: Rivers flowing after folding of an area in a direction opposite to the initial consequent drainage system, involving reversal of antecedent river segments

Superposed: Rivers incised in strata that do not control their course that was inherited from the configuration of overlying strata or landforms

A step-wise reconstruction of tectonic processes, which controlled the development of this drainage system starting in Oligocene times, is presented in the following sections.

\section{Oligocene to early Miocene Rhine Graben stage of the Jura domain}

During the Oligocene and early Aquitanian, intermittent communications were established between the flexural Molasse Basin and the rifted URG via the Rauracian Depression that crossed the area of the future Eastern Jura Mountains in the SW prolongation of the URG (Kuhlemann \& Kempf 2002; Berger et al. 2005a). The axial parts of this shallow depression coincide with the valley-and-ridge province of the Jura Mountains and were controlled by tensional fault systems that extend from the URG SW-ward (Laubscher 1981, 1998, 2003). In this area, the middle and late Aquitanian corresponds to an erosional hiatus, which has been variably attributed to the development of an Alpine flexural forebulge (Laubscher 1992, 2001) or to the build-up of intraplate compressional stresses causing transpressional reactivation of pre-existing basement disconti- 
nuities (Laubscher 2003; Ziegler \& Dèzes 2007). In response to these deformations, the conglomeratic "older Jura Nagelfluh" (upper Aquitanian?) was shed SE-ward from the Black Forest into the area of the Tabular Jura (Diebold et al. 2006) and the Hegau (Schreiner 1965; Müller et al. 2002). These depositional areas formed part of the northern margin of the continuously subsiding Molasse Basin in which fluvial clastics derived from the Alps were transported ENE-ward since the late Oligocene (Untere Süsswassermolasse, USM).

During the early Burdigalian the Molasse Basin was invaded by seas, which entered it from the SW and E. During this "Obere Meeresmolasse" transgression (OMM, 21-20 Ma) the Molasse Basin narrowed and deepened whilst its northern parts were uplifted and subjected to erosion (Kuhlemann \& Kempf 2002), reflecting increasing collisional coupling between the Alpine orogenic wedge and its foreland (Ziegler et al. 2002). During the late Burdigalian high-stand in sea level, much of the area of the future Jura Mountains was overstepped again by transgressions advancing from the Molasse Basin, controlling the deposition of brackish-marine series (Kuhlemann \& Kempf 2002; Berger et al. 2005a; Bieg 2005).

\section{Late Burdigalian uplift of the Vosges-Black Forest Arch}

At about $18 \mathrm{Ma}$ lithospheric folding controlled rapid uplift of the Vosges-Black Forest Arch, which at the level of the Moho discontinuity extends from the Massif Central to the Bohemian Massif. In the process of this, the southern parts of the URG were uplifted and its border faults transpressionally reactivated (Dèzes et al. 2004; Rotstein et al. 2005a; Ziegler \& Dèzes 2007). Moreover, a regional erosional unconformity spanning 18.3-17.8 Ma developed in the Swiss Molasse Basin (Kempf et al. 1999). These deformations reflect that intraplate compressional stresses built up in the foreland of the Alps during the early phases of imbrication of their external crystalline massifs (Fügenschuh \& Schmid 2003; Dèzes et al. 2004).

During the late Burdigalian the WSW-directed estuarine "Glimmersand" stream developed in the Molasse Basin in a depression, which straddled its present-day northern margin. This depression was flanked to the south by alluvial fans, which originated in the Alps, whilst to the north it was flanked by the Vosges-Black Forest Arch and its extension into the Bohemian Massif. This fluvial to lacustrine drainage system (Obere Süsswassermolasse, OSM) persisted, despite falling sea levels, during Langhian and Serravallian times and probably even during the earlier parts of the Tortonian (Fig. 4; Hofmann 1960, 1996; Kuhlemann \& Kempf 2002; Berger et al. 2005a; Bieg 2005). Compared to the late Oligocene-early Miocene ENE directed drainage system of the Molasse Basin, the late Burdigalian development of the WSW directed Glimmersand systems reflects a reversal of its drainage pattern (Kuhlemann \& Kempf 2002). This suggests that during the late Burdigalian to Serravallian early uplift phases of the Central Alpine External Massifs, the western parts of the Molasse Basin subsided faster than its eastern parts.
Late Burdigalian uplift of the Vosges-Black Forest Arch caused the development of a S- and SE-directed consequent drainage system on its southern flank that debouched into the Glimmersand depression. In the domain of the future Eastern Jura Mountains and the Hegau, related rivers initially truncated the OMM and locally incised into Jurassic carbonates, forming up to $100 \mathrm{~m}$ deep valleys, and later controlled the deposition of the Vosges-derived "Bois de Raube" and the Black Forestderived "Jura Nagelfluh" formations (Fig. 4; Liniger 1953, 1966, 1967; Hofmann 1996; Kälin 1997; Berger et al. 2005a). In the Jura Mountain valley-and-ridge province, remnants of the Bois de Raube and the Jura Nagelfluh formations are preserved in the broad Delémont and Laufen synclines. These attain thicknesses of up to $130 \mathrm{~m}$, span Serravallian to early Tortonian times (14.5-9.8 Ma) and consist of predominantly coarse fluvial conglomerates and minor sands and marls (Kälin 1997; Kemna \& Becker-Haumann 2003; Braillard 2006). In the Tabular Jura, the so-called "younger Jura Nagelfluh" is preserved near the thrust front as a coherent, up to $200 \mathrm{~m}$ thick sequence of lacustrine marls and freshwater carbonates that contains intercalations of fluvial sands and conglomeratic layers. This sequence dips $3-4^{\circ}$ to the south, rests unconformably on truncated OMM and Late Jurassic series, spans Serravallian to earliest Tortonian times and grades southward into the Glimmersand facies of the OSM (Diebold et al. 2006; Berger et al. 2005b). In the Hegau, remnants of the "younger Jura Nagelfluh" range in age from late Burdigalian to late Serravallian (17.5-12 Ma) and similarly grade SE-ward into the OSM Glimmersand, which probably extends into the early Tortonian (Hofmann 1960, 1969, 1996; Müller et al. 2002; Kuhlemann \& Kempf 2002; Bieg 2005; Rahn \& Selbekk 2007).

Additional remnants of the Bois de Raube and Jura Nagelfluh formations have been reported from the more internal parts of the Jura Mountain valley-and-ridge province to the SW and S of the Delémont and Laufen synclines (e.g. Montfaucon, Bellelay, Mt. Raimeux, Vermes, Schelten Pass). Moreover, scattered remnants of the probably time-equivalent "Höhenschotter" have an even wider distribution and occur as far south as the Pierre Pertuis wind gap (Liniger 1953). Therefore, the underlying south-directed drainage system probably extended across the entire area of the future Jura Mountains and linked up with that of the Glimmersand Depression along the northern margin of the Molasse Basin (Liniger 1966; Hofmann 1969, 1996; Kälin 1997; Berger et al. 2005a). The conglomeratic fans of the Jura Nagelfluh and Bois de Raube formations were apparently channelled by fault systems that extended southward from the Rhine Graben into the area of the future Jura Mountains, such as the Wehratal-Zeiningen fault, the Rhine Valley Flexure and the Allschwil, Ferrette-Caquerelle, Illfurth and Belfort faults (Figs. 2 \& 4; Liniger 1966; Kälin 1997; Laubscher 2001; Kemna \& Becker-Haumann 2003). Similarly, the "younger Jura Nagelfluh" fans of the Hegau were apparently channelled by reactivated basement faults of the Hegau-Bodensee Graben (Schreiner 1965; Hofmann 1996; Müller et al. 2002). By contrast, the "younger Jura Nagelfluh" of the Tabular Jura, with a clearly

62 P.A. Ziegler \& M. Fraefel 


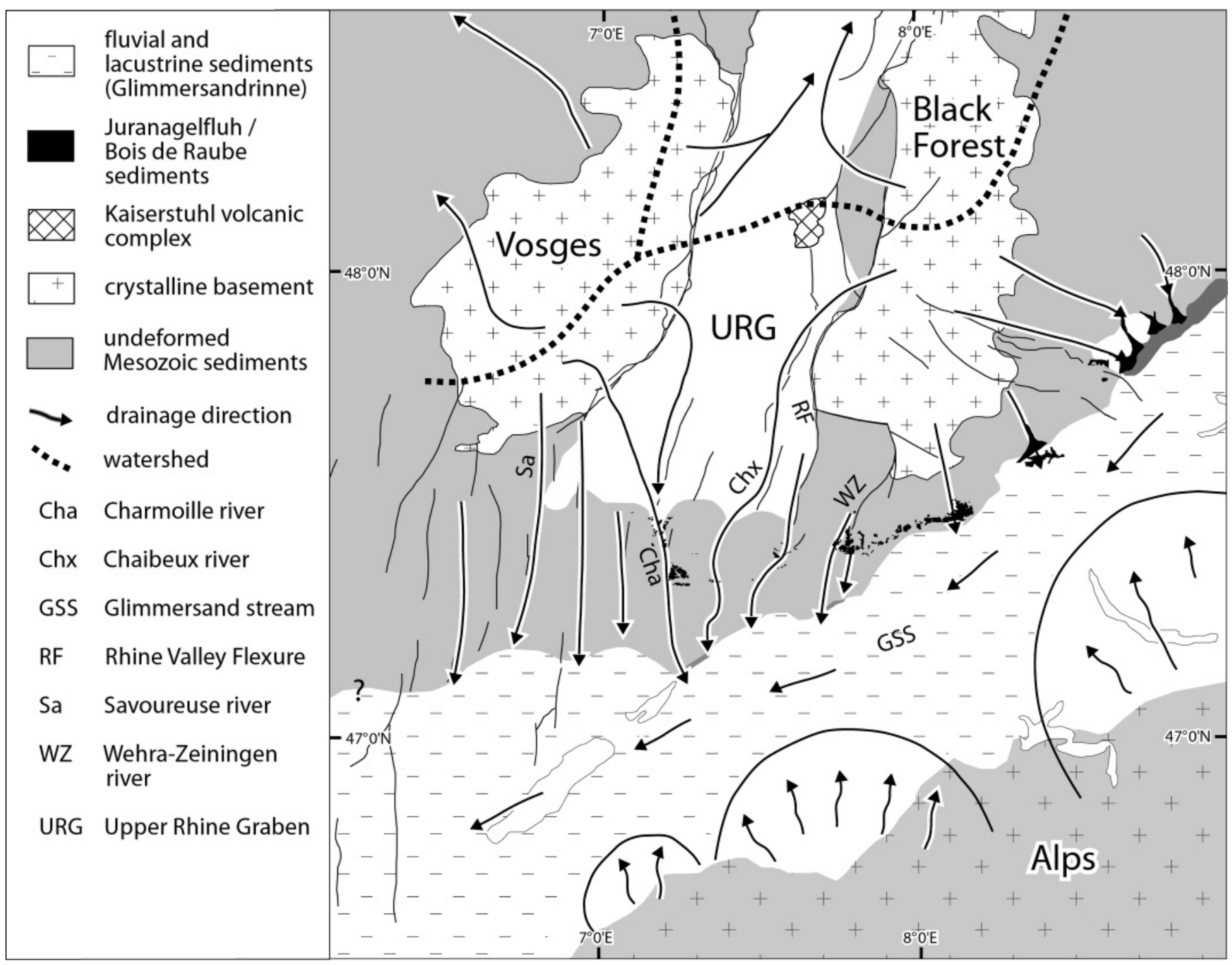

Fig. 4. Serravallian to early Tortonian (Jura Nagelfluh stage, 13.6-10 Ma, no palinspastic restoration). The SW flowing Glimmersand stream drains the Molasse Basin whilst from a watershed near the Kaiserstuhl the proto-Rhine flows N in the Upper Rhine Graben.

erosional base, was apparently deposited on a near-planar Sto SE-dipping surface against which it on-lapped northward (Diebold et al. 2006).

As the top of the Jura Nagelfluh and its equivalents is erosional everywhere, their youngest parts are missing and may have extended into the middle or even the late Tortonian (10-7.2 Ma), particularly in the external parts of the Jura Mountains. The size of clasts contained in the Jura Nagelfluh and Bois de Raube formations (Kälin 1997; Kemna \& BeckerHaumann 2003), and their incision into Oligocene sediments and Jurassic carbonates (Liniger 1966,1967), are indicative of clastic transport by relatively high-energy rivers. Deep truncation to total removal of the Jura Nagelfluh and its equivalents in the more internal parts of the valley-and-ridge province of the Jura Mountains renders it impossible to reconstruct details of the underlying drainage system. Yet, circumstan- tial evidence for the configuration of this drainage system is provided by the distribution of wind and water gaps, which were incised by Jura Nagelfluh streams into anticlines that started to grow during the early deformation phases of the JFTB (Liniger 1953).

\section{Late Miocene to early Pliocene folding phase of the Jura Mountains}

As the Jura Nagelfluh and its equivalents are clearly involved in the structures of the Eastern JFTB (Liniger 1966; Laubscher 1998, 2001; Diebold et al. 2006), and as there is no evidence for their syn-depositional deformation (Kälin 1997), it is unlikely that the main parts of the JFTB were activated before the middle Tortonian (10-9 Ma). Nevertheless, in the southernmost parts of the JFTB, which branch off from the Subalpine Chains 


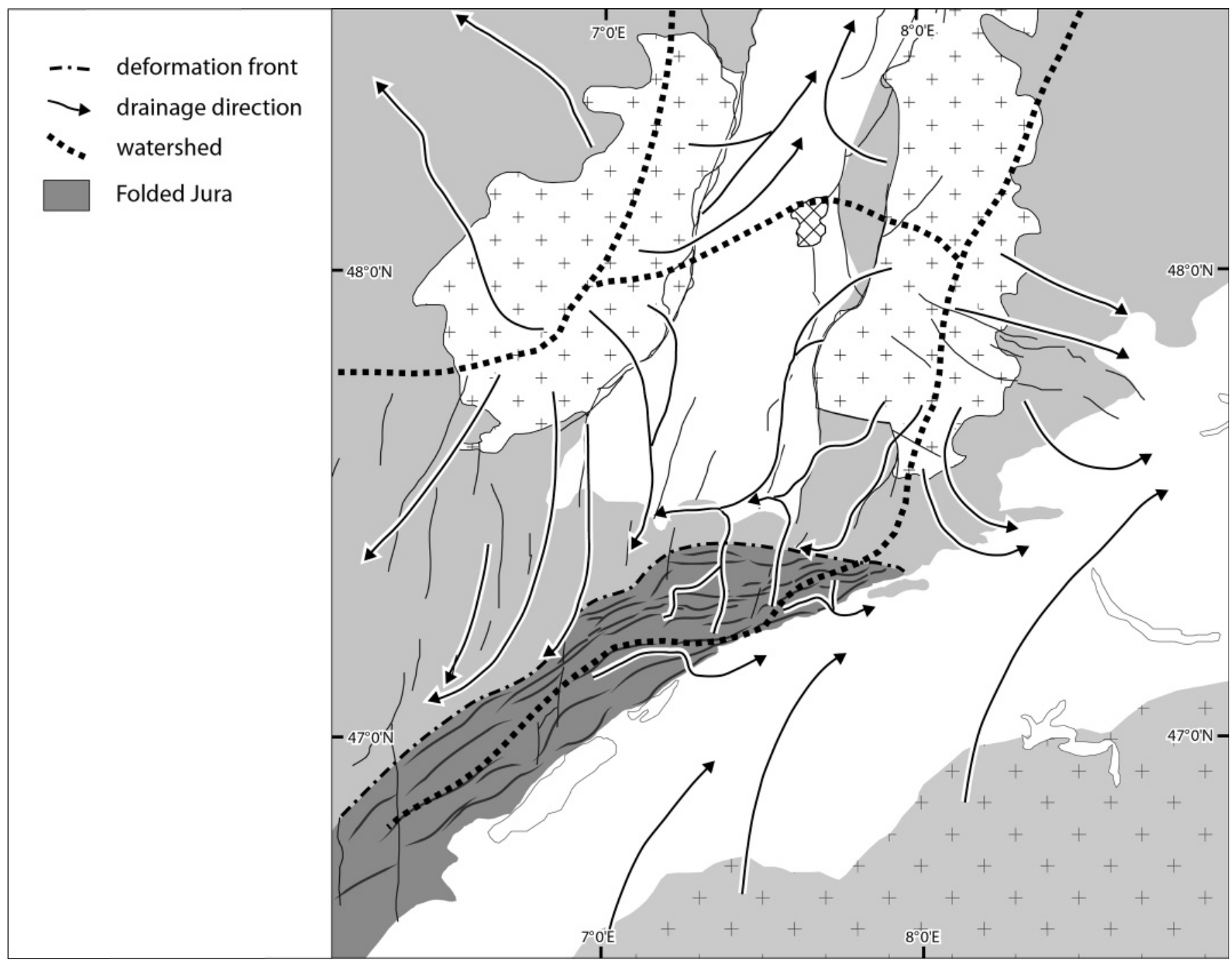

Fig. 5. Middle to late Tortonian (early folding phases of the Jura Mountains, 10-7.2 Ma, no palinspastic restoration). The drainage direction of the Molasse Basin has changed to NE; a new watershed has formed in the Jura fold-and-thrust belt.

near Chambéry, thrusting had commenced already during the Burdigalian (Deville et al. 1994).

Shortening in the essentially thin-skinned JFTB is kinematically linked to the Alps by thrust faults which ramp up through the upper crust at the northern margin of their external Aare, Aiguilles Rouges and Belledonne massifs, extend as sole-thrusts in Triassic sediments across the Molasse Basin and ramp up in the Jura Mountains in multiple splays through Triassic and Jurassic series. In the hanging wall of these solethrusts the sedimentary fill of the Molasse Basin was passively translated NW-ward, uplifted and tilted to the NE (Laubscher 1961, 1992; Guellec et al. 1990; Burkhard \& Sommaruga 1998; Affolter \& Gratier 2004). Uplift and erosional unroofing of the external Alpine massifs accelerated around $10 \mathrm{Ma}$ (Fügenschuh \& Schmid 2003) and, thus, is compatible with an
intra-Tortonian onset of the main deformation phase of the JFTB.

\subsection{Drainage reversal in the Molasse Basin}

In the course of the middle Tortonian (10-9 Ma), the WSW-directed Glimmersand drainage system was abandoned owing to uplift and NE-ward tilting of the western parts of the Swiss Molasse Basin during the early folding phases of the Jura Mountains. With this, a new ENE-directed drainage system began to develop that can be regarded as the precursor of the AareDanube system (Fig. 5; Hofmann 1960, 1996; Müller et al. 2002; Kuhlemann \& Kempf 2002; Berger et al. 2005a). In this context it is important to note that the preserved sedimentary record

64 P.A. Ziegler \& M. Fraefel 


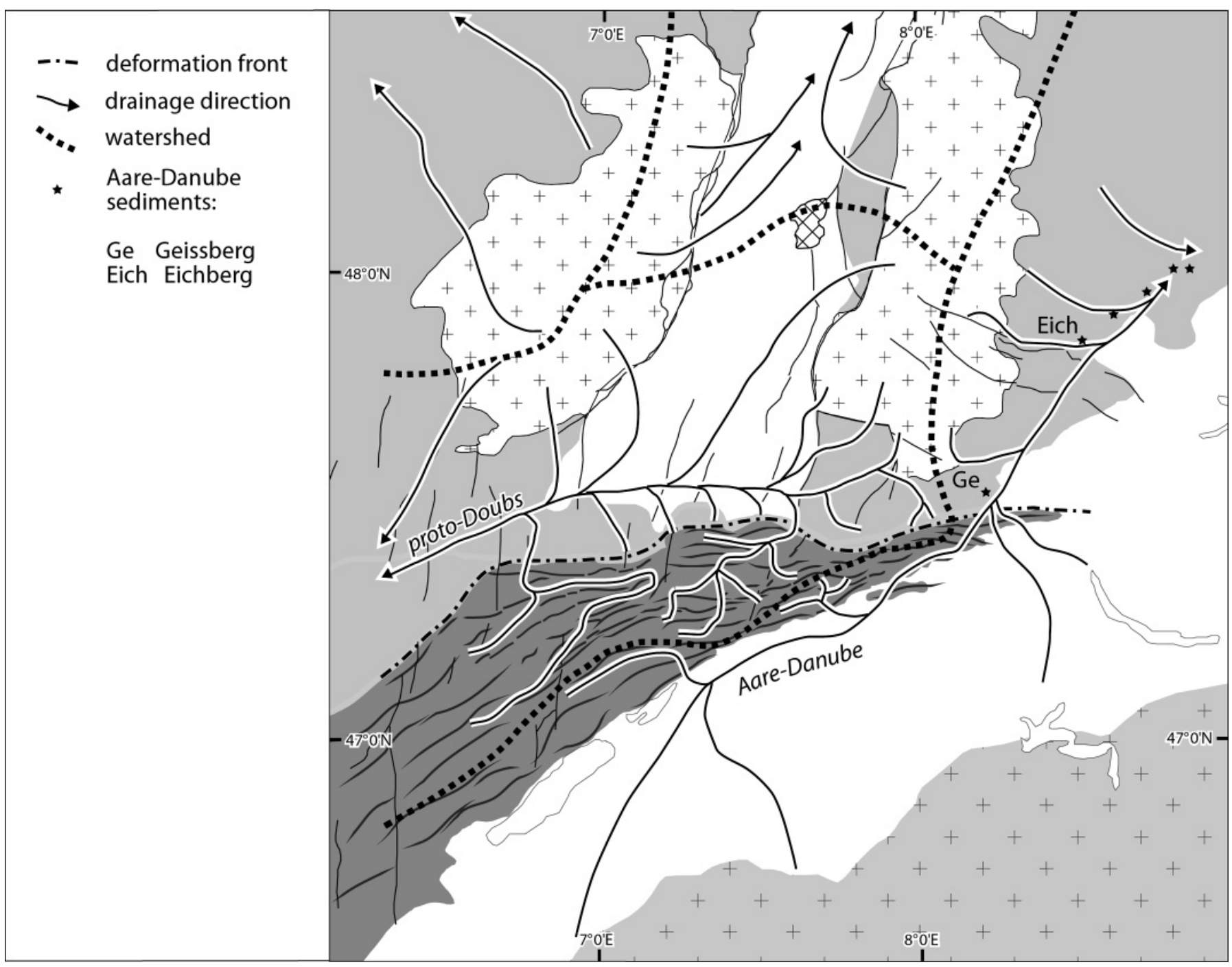

Fig. 6. Messinian to early Pliocene (Aare-Danube and proto-Doubs stage, 7.2-4.2 Ma, no palinspastic restoration). Sediments attributed to the river AareDanube occur on the SE flank of the Black Forest. The headwaters of the proto-Doubs extend into the foreland of the Jura fold-and-thrust belt.

of the Swiss Molasse Basin ends in the Serravallian, and that about $700 \mathrm{~m}$ of sediments have been eroded from its eastern parts and over $2000 \mathrm{~m}$ from its western parts. Correspondingly, the timing of this drainage reversal is poorly constrained in Switzerland and has been inferred from the middle Tortonian NE- and E-ward deflection of Alpine alluvial fans in the Bavarian and Upper Austrian Molasse Basin (Kuhlemann \& Kempf 2002; Müller et al. 2002; Berger et al. 2005a, b).

The ENE-flowing former Aare-Danube River is documented by undated relics of epidote-bearing quartz gravels occurring in the lower Aare valley (Geissberg near Villigen), on the eastern flank of the Black Forest (Eichberg near Blumberg) and in the upper Danube valley (Fig. 6). This river presumably came into existence during the late Tortonian (8-7.2 Ma) or in the course of the Messinian (7.2-5.3 Ma) and persisted until the early Pliocene (4.2 Ma) (Hofmann 1996; Villinger 1998, 2003; Müller et al. 2002; Berger et al. 2005a, b; Sissingh 2006).

\subsection{Drainage reversal in the valley-and-ridge province}

The occurrence of water and wind gaps is largely limited to the valley-and-ridge province of the Eastern Jura Mountains, which is characterized by major, thrust-related flexural-slip folds and large synclinal depressions. Nearly linear chains of water and wind gaps cutting across adjacent anticlines are interpreted as marking branches of the antecedent south-directed Jura Nagelfluh drainage system, which had begun to incise into growing anticlines during the middle and late Tortonian (Liniger 1953). For example, water and wind gaps seem to be aligned in the 
southward prolongation of the Wehratal-Zeiningen fault system and the Rhine Valley Flexure (Fig. 2). Similarly, N-S and NNE-SSW aligned wind and water gaps indicate the course of former southward flowing rivers in the prolongation of the Allschwil and Ferrette faults, corresponding to the Chaibeux Jura Nagelfluh river and the Charmoille Bois de Raube river as defined by Liniger (1953) (Fig. 4). Locally river incision was apparently accompanied by the development of doubly plunging anticlines (Simpson 2004a, b) as seen at Soyhières and Tiergarten.

In the course of the evolution of the JFTB, involving rapid and perhaps not strictly in-sequence NW-ward fold and thrust propagation (see analogue model of Philippe et al. 1996), the southward flowing consequent Jura Nagelfluh drainage system was gradually overpowered and partly reversed. This led to the development of new drainage systems consisting of subsequent and obsequent segments (e.g. river Birs), or subsequent and resequent segments (e.g. river Dünnern; Fig. 3). Unfortunately, the exact timing of the different steps in this drainage reorganization cannot be further constrained for want of a corresponding sedimentary record. As folding continued, some earlier formed water gaps were employed by the new drainage systems, which accounted for their further incision into growing anticlines, whilst others were abandoned and uplifted and now form wind gaps. This drainage reorganization also explains why some present-day creeks with small drainage areas, corresponding to low discharge, employ large gaps that they cannot have incised on their own (e.g. Soyhières, Tiergarten, Gänsbrunnen gaps; Fig. 2).

These new drainage systems also interacted with anticlinal structures that started to develop in the younger, more external parts of the Jura Mountains. Of special interest are anticlines that lack wind and water gaps. These were either not transected by antecedent rivers during the initial stage of their evolution or they developed only after such rivers had been abandoned. For instance, the external Bueberg, Glaserberg and Blauen anticlines are not breached by water gaps, apart from the Laufen gap through the eastern end of the Bueberg structure (Fig. 2). These anticlines probably began to develop during a later stage (late Tortonian-Messinian?), after the Jura Nagelfluh drainage system had been abandoned and the northward flowing river Birs had been established. Correspondingly, it is likely that it was the river Birs that cut the Laufen and Angenstein gaps through the eastern, plunging ends of the Bueberg and Blauen anticlines, respectively. Incision of two partial wind gaps in the western part of the Bueberg anticline presumably commenced during this drainage system reorganization and continued subsequently in response to headward erosion by the subsequent river La Lucelle that flows eastward between the Bueberg and Glaserberg anticlines.

The fact that even the most internal anticlines of the JFTB are locally breached by water gaps, such as near Bienne and Oensingen (Fig. 2), supports the hypothesis that antecedent rivers once crossed the entire Jura Mountain domain and probably built out fans on the floodplain of the Glimmersand Depres- sion, as already inferred above from the distribution of the Jura Nagelfluh, Bois de Raube and equivalent sediments (Fig. 4). On the other hand, an embayment of the Glimmersand Depression may have extended between Bienne and Oensingen across the area of the Montoz and Weissenstein anticlines, which are not cut by water gaps, whilst the Graitery anticline to the north is transected by the Court water gap and the Gänsbrunnen wind gap. This interpretation is compatible with the occurrence of Glimmersand intercalations in the Tortonian (Serravallian?) lacustrine carbonates of the Court syncline, which separates the Graitery and Montoz-Weissenstein anticlines, as well as in those of the St. Imier syncline (Hofmann 1969).

\subsection{Franches-Montagnes and Franche-Comté}

During the middle and late Tortonian, the deformation front of the JFTB apparently advanced across the Franches-Montagnes and reached the Faisceau Salinois by early Pliocene times. This narrow deformation belt links up to the NE with the Mont Terri anticline and the SW with the Lédonien thrust sheet (Figs. 1 \& 2). The latter overrode the eastern margin of the Bresse Graben at the Miocene-Pliocene transition (Chauve et al. 1980, 1988; Guellec et al. 1990; Roure et al. 1994). Moreover, it is likely that the Lomont anticline, which lies on trend with the Mont Terri, Bueberg and Glaserberg anticlines, was activated during the Messinian to early Pliocene whilst deformation of the Faisceau Bisontin may have begun during the early Pliocene (Figs. $5 \& 6$ ).

In this area several prominent water gaps occur that can be linked to roughly NNE-SSW trending faults, which extend from the URG and the Vosges into the Jura domain, such as the Illfurth and Belfort faults, and probably exerted controls on the antecedent late Miocene drainage system (Figs. 2 \& 4). Several water gaps of the rivers Doubs and Dessoubre are located in the southward prolongation of the river Savoureuse, which now flows from the Vosges Mountains into the Doubs (Fig. 3); however, it might once have been part of a longer river that flowed southward towards the Molasse Basin, following Vosgian fracture systems. Thus we assume that the upper reaches of the river Doubs developed during the late Tortonian to early Pliocene deformation of the JFTB, consequently employing synclinal valleys and obsequently using water gaps initially cut through rising anticlines by southward-flowing consequent Vosgian rivers. From Montbéliard the meandering proto-Doubs flowed SW-ward towards the Bresse Graben in a gentle depression that was flanked to the SE by the Faisceau Bisontin, which marks the boundary between the Ornans Plateau, the Avant-Monts Zone and the Montbéliard Plateau (Fig. 1; Madritsch et al. (2008)).

\subsection{Eastern thrust belt}

In the thrust-dominated easternmost Jura Mountains, water gaps occur only where the river Aare, and its tributaries Reuss and Limmat, incised into the evolving fold-thrust belt (Fig. 2).

66 P.A. Ziegler \& M. Fraefel 


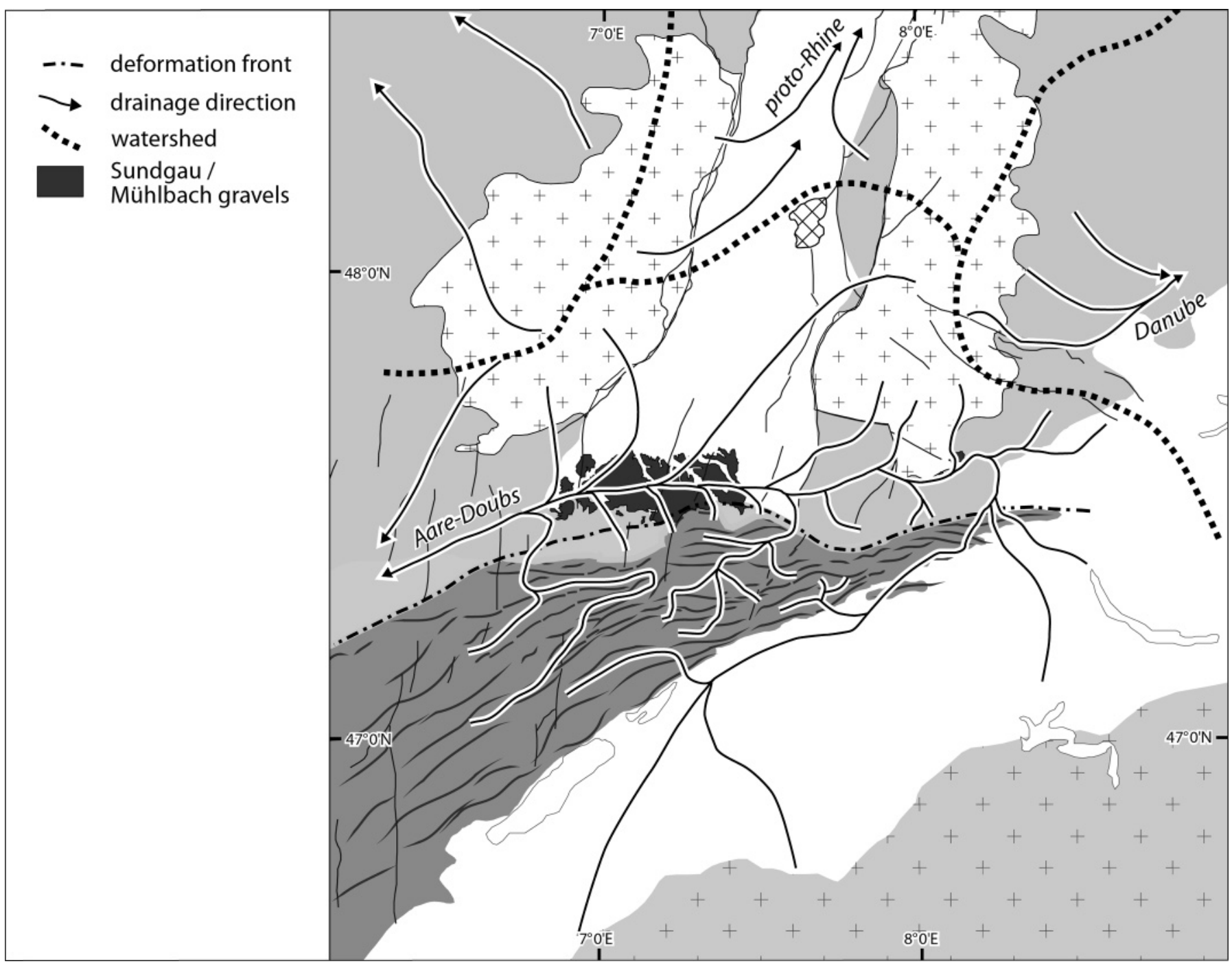

Fig. 7. Mid-Pliocene (Aare-Doubs stage, 4.2-2.9 Ma, no palinspastic restoration). In response to headward erosion of the proto-Doubs, the river Aare is deflected to the W. The river Aare-Doubs deposits the Sundgau Gravels.

South of the city of Olten the doubly plunging Born anticline is transected at its culmination by the river Aare, and thus conforms to the erosion-induced anticlinal growth model (Simpson 2004a, b; see Ziegler \& Dèzes 2007). Yet, the thrust stack immediately to the north of Olten is not breached by water or wind gaps. Therefore we postulate that antecedent rivers originating in the Black Forest were not able to cut water gaps in this area. This is compatible with the fact that in this part of the Jura Mountains the "younger Jura Nagelfluh" deposits display a distinctly lacustrine affinity (Diebold et al.2006) that does not imply the presence of persisting high-energy streams. Based on these considerations, and assuming that the thin-skinned Born anticline is not a late out-of-sequence structure, we postulate that deformation of the easternmost parts of the Jura Mountains commenced only after the Aare-Danube and its tributary rivers Reuss and Limmat had been established, perhaps as early as during the late Tortonian (8.0-7.2 Ma) or more likely in the course of the Messinian (7.2-5.3 Ma). This would account for the development of the water gaps that these rivers carved through the eastern-most elements of the JFTB. It is noteworthy that the Aare-Danube drainage system essentially employed the Glimmersand drainage system in an obsequent mode (Figs. 5 and 6).

\section{Pliocene and Quaternary reorganization of drainage systems in the foreland of the Jura Mountains}

During the late early Pliocene (4.2 Ma) the palaeo-Aare river was deflected into a western direction at the eastern end of the JFTB near Waldshut and began to flow along the southern flank of the Black Forest in an isoclinal valley of the Tabular Jura towards the Sundgau and via the Franche-Comté, the Bresse 
Graben and the Rhône Valley into the Mediterranean (Fig. 7; Liniger 1966, 1967; Hofmann 1996; Villinger 1998; Laubscher 2001; Sissingh 2006). This Aare-Doubs deposited gravels dominated by Alpine clasts in the Sundgau, on the Vesoul-Montbéliard Plateau and Forêt de Chaux as well as in the Bresse Graben. In the Forêt de Chaux and Bresse Graben these gravels are known as "Cailloutis de Desnes" and are dated as 4.2-2.9 Ma (Petit et al. 1996; Fejfar et al. 1998). These gravels were uplifted and eroded throughout the Besançon Zone, which represents the NW-most segment of the JFTB (Madritsch et al. 2008), but are preserved in the Sundgau area. These "Sundgau Gravels" were deposited on a nearly planar, relatively wide surface by a shallow braided stream system, characterized by shifting channels, and form an up to $30 \mathrm{~m}$ thick layer (Giamboni et al. 2004a, b). The base of these gravels is erosional and there is evidence for reworking of the underlying Bois de Raube formation (Liniger 1967; Braillard 2006).

Deflection of the river Aare towards the west is attributed to its capture by the proto-Doubs drainage system, which had developed in front of the evolving JFTB during the late Tortonian and Messinian and collected the consequent Vosges and Black Forest and the new obsequent Jura rivers. By early Pliocene times, the headwaters of the proto-Doubs drainage systems, which had its base level in the subsiding Bresse Graben (Ziegler and Dèzes 2007), extended into the foreland of the Eastern Jura thrust belt and started to interfere with the AareDanube drainage system, ultimately capturing the river Aare around 4.2 Ma (Fig. 6; Liniger 1966; Hofmann 1996; Villinger 1998; Sissingh 2006). With this, the water and sediment load of the newly established Aare-Doubs increased sharply (Fig. 7).

During these times the proto-Rhine flowed northward from a watershed near the Kaiserstuhl into the continuously subsiding northern parts of the transtensional URG (Hagedorn 2004; Hagedorn \& Boenigk 2008; Haimberger et al. 2005; Lopes Cardozo \& Behrmann 2006). Rivers originating on the southern slopes of the Black Forest Massif, corresponding to the headwaters of the S-flowing consequent Jura Nagelfluh drainage system now debouched into the westward flowing Aare-Doubs (Villinger 1999). Similarly, the obsequent drainage system of the Tabular Jura in front of the Jura thrust belt and the combined subsequent and obsequent drainage system of the Jura valleyand-ridge province formed tributaries of the Aare-Doubs. This is compatible with the compositional spectrum of the Sundgau Gravel components (Liniger 1967).

The Aare-Doubs drainage system persisted until about 2.9 Ma (Fejfar et al. 1998) when the river Aare was deflected into the URG at Basel and joined the northward flowing protoRhine, thus forming the Aare-Rhine (Fig. 8; Liniger 1966; Villinger 1998; Laubscher 2001; Giamboni et al. 2004a, b). In the sedimentary record of the URG, this is reflected by a massive influx of Alpine heavy minerals, commencing towards the end of the late Pliocene (Hagedorn 2004; Hagedorn \& Boenigk 2008; Rolf et al. 2008). In the Lower Rhine Graben, however, the first occurrence of Alpine heavy minerals has been reported from the Oebel Beds of the Waalre-1 Formation, which clearly pre-dates the Pliocene-Quaternary boundary (GaussMatuyama magnetic reversal at 2.58 Ma; Kemna 2008) and has been tentatively assigned an age of 2.8-2.58 Ma (Westerhoff et al. 2008).

Owing to the late Pliocene diversion of the river Aare into the URG, the water and sediment load of the river Doubs decreased sharply. Deflection of the Aare into the Rhine drainage system was induced by transtensional subsidence of the southern parts of the URG, resuming during the late Pliocene and continuing to the present, as evidenced by the occurrence of up to $240 \mathrm{~m}$ of upper Pliocene and Quaternary sediment in the fault-controlled Geiswasser Basin adjacent to the Kaiserstuhl (Bartz 1974; Dèzes et al. 2004; Lang et al. 2005; Ziegler \& Dèzes 2007). Late Pliocene and Quaternary subsidence of the URG was accompanied by a gradual lowering of its alluvial plain, and with this, a lowering of the erosional base level of the AareRhine. Outside the graben this led to the progressive incision of the Aare-Rhine and its tributaries, such as the Klettgau-Rhine. As a result, around $1.7 \mathrm{Ma}$, the latter captured the Alpine headwaters of the river Rhine in the area of Lake Constance in response to headward erosion, assisted by the run-off of glacial melt waters during the Donau/Günz glacial stages (Fig. 9; Villinger 2003). With this, the water and sedimentary load of the newly formed Alpine Rhine increased strongly (Hofmann 1996; Villinger 1998, 2003; Müller et al. 2002; Hagedorn 2004, Hagedorn \& Boenigk 2008).

During the Quaternary the Alpine Rhine and its tributaries in the Jura Mountains and the Black Forest continued to incise in response to progressive lowering of their erosional base level in the continuously subsiding URG, and possibly to gentle uplift of the Black Forest. This is evidenced by distinct cut-and-fill terrace systems of the Alpine Rhine upstream from Basel and along the lower reaches of the river Aare (Haldimann et al. 1984; Verderber 1992, 2003; Müller et al. 2002). On the eastern flank of the Black Forest, continuing river incision resulted in the capture of the Feldberg-Danube by the river Wutach, a tributary of the Rhine, between 19-20 ka (Hofmann 1996; Villinger 2003).

\section{Evidence for Pliocene and Quaternary tectonic activity}

In the foreland of the Eastern Jura thrust belt, the thinskinned Mandach and Mettau thrusts (Fig. 2a; Bitterli \& Matousek 1991; Diebold et al. 2006) probably developed during the Quaternary. This is suggested by the occurrence of remnants of "Höhere Deckenschotter" gravels (2.6-1.6 Ma) $\mathrm{N}$ of the Mandach thrust that were deposited by a northward flowing river, the course of which was apparently blocked by the development of the Mandach thrust (Müller et al. 2002). Moreover, the Etzgerbach and Sulzerbach rivers originate on the northern flank of the Mandach structure, which is not breached by gaps, and cut through the Mettau thrust in water gaps (Fig. 2b). Therefore, these creeks probably developed on the northern slope of the Mandach structure prior to activation of the Mettau thrust. Furthermore, minor compres-

68 P.A. Ziegler \& M. Fraefel 


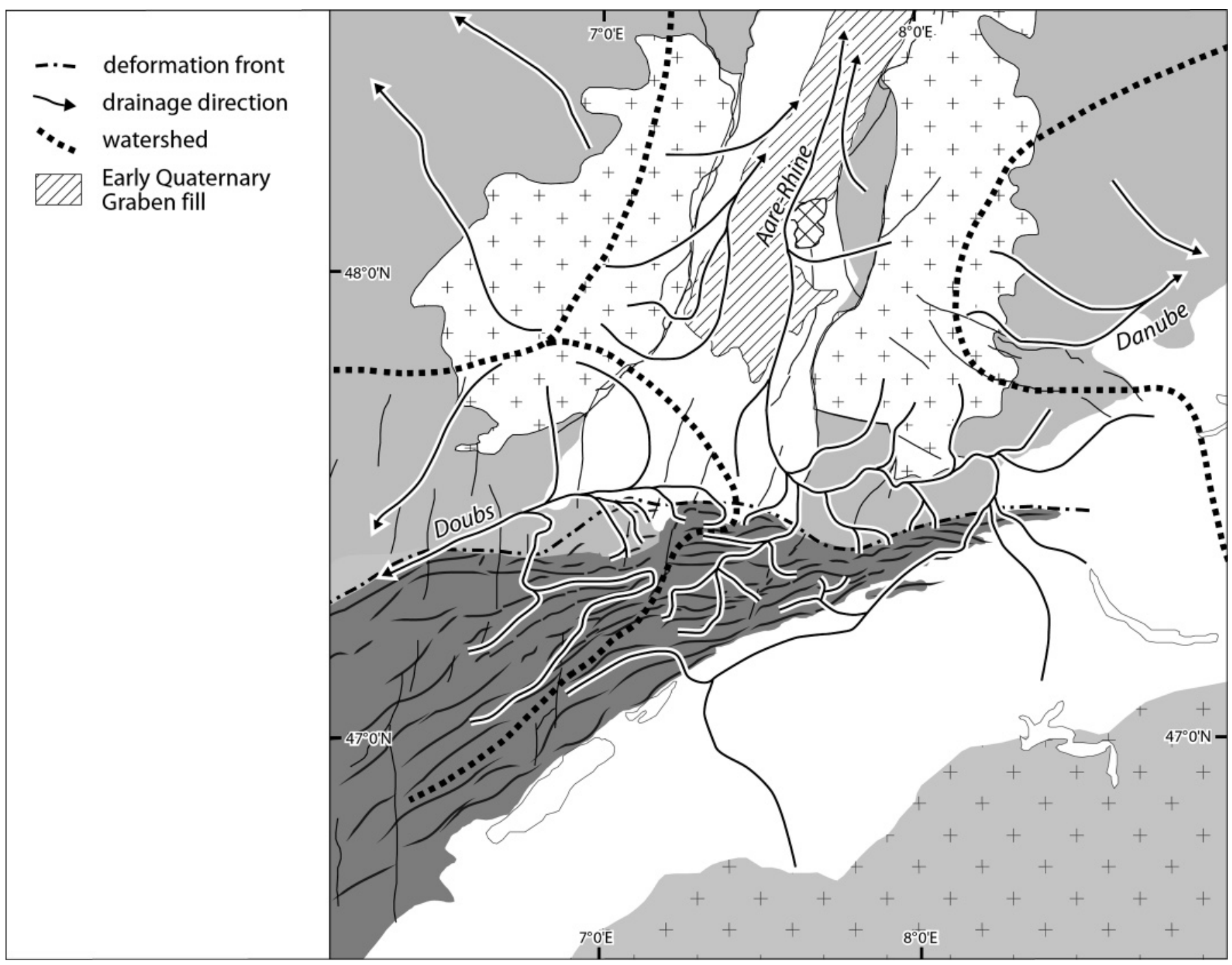

Fig. 8. Late Pliocene to early Quaternary (Aare-Rhine and Doubs stage, 2.9-1.7 Ma, no palinspastic restoration). The river Aare is deflected into the Upper Rhine Graben. Headward erosion of Aare tributaries intensifies in response to lowering of the base level in the subsiding Upper Rhine Graben.

sional structures observed in the projection of the Mandach thrust and at Klingnau in the lower Aare Valley may have been active during the Quaternary (Haldimann et al. 1984; Müller et al. 2002).

Upstream from Basel, small remnants of the Sundgau Gravel equivalent Mühlbach Series are preserved between Laufenburg and Waldshut (Hofmann 1996; Verderber 2003). These deeply weathered gravels are characterized by the same heavy mineral spectrum as the Pliocene Sundgau Gravels (4.2-2.9 Ma). Moreover, sediment-petrographically they differ profoundly from the garnet-rich "Höhere Deckenschotter" gravels (Hofmann 1996) that range in age between 2.6 and 1.6 Ma (Müller et al. 2002; Villinger 2003). In view of this, and as the Mühlbach Series is characterized by normal magnetisation (Fromm 1989), it was probably deposited during the
Pliocene Gauss epoch (3.580-2.588 Ma) rather than during the early Quaternary Olduvai epoch (1.95-1.77-Ma), as postulated by Verderber (2003).

In the Rhine Valley upstream from Basel the distribution of remnants of Sundgau Gravel equivalent deposits (4.2-2.9 Ma) and of older river terraces ("Deckenschotter", $2.6-0.78 \mathrm{Ma}$ ) is generally too limited to record potential tectonic activity along fault systems extending from the Black Forest into the Tabular Jura. Nevertheless, scattered remnants of the Deckenschotter suggest a subtle gradient increase across the Rhine Valley flexure, indicative of its tensional reactivation (S. Kock, pers. comm.). The uniform gradients of the well-preserved younger Rhine river terraces ("Hoch- and Niederterrassen") suggests that during the last $0.78 \mathrm{Ma}$ the fault systems of the Black Forest and Tabular Jura were essentially quiescent, perhaps with 


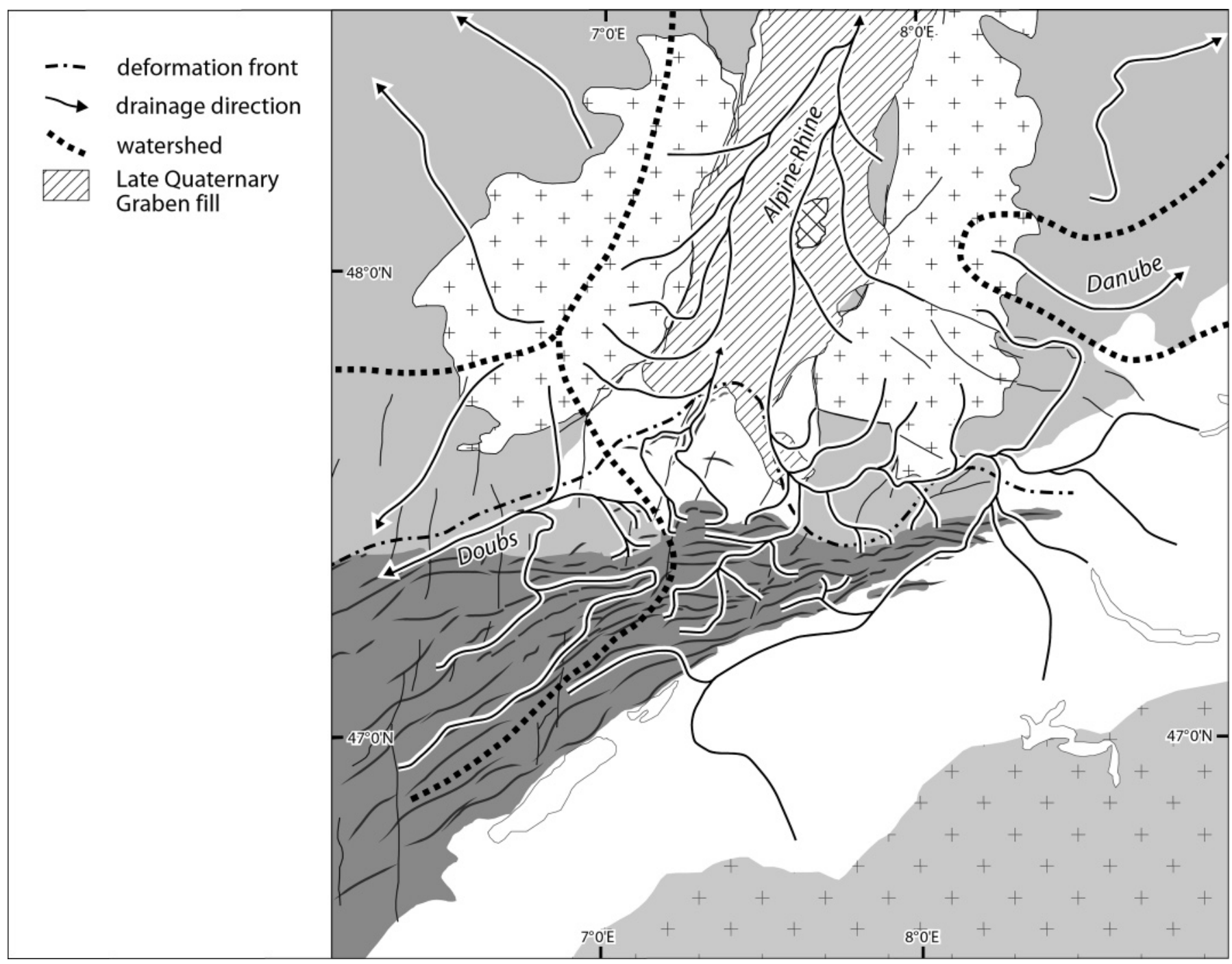

Fig. 9. Late Quaternary (Alpine Rhine and Doubs stage, 1.7-0 Ma). Capture of the Alpine Rhine and the headwaters of the Danube by tributaries of the river Aare.

exception of the Rhine Valley flexure across which Niederterrasse gradients increase gently (Haldimann et al. 1984; Verderber 1992, 2003).

In the Sundgau, by contrast, the Pliocene Sundgau Gravels are still well preserved in front of the valley-and-ridge province of the Jura Mountains where they were deposited on a wide floodplain. In the Bresse Graben their equivalents (Desnes Gravels) attain thicknesses of up to $300 \mathrm{~m}$ (Petit et al. 1996; Giamboni et al. 2004b), thus attesting to its tensional reactivation (Dèzes et al. 2004). In the Sundgau and Ajoie, the Sundgau Gravels are involved in the frontal folds of the Jura Mountains. Moreover, there is evidence for Quaternary changes in drainage patterns and anomalies in river gradients, as well as for the deformation of terraces, indicating late stage compressional deformation of the Mulhouse High (Nivière \& Winter 2000; Giamboni et al. 2004a, b; Carretier et al. 2006) and the Ajoie (Brail- lard 2006). Deformation of the Mulhouse High and its Sundgau Gravel cover involved the development of several gentle folds (Giamboni et al.2004b) and sinistral reactivation of the Paleogene URG-related Illfurth fault (Fig. 2a; Le Carlier de Veslud et al. 2005; Rotstein et al. 2005b; Ustaszewski \& Schmid 2007). The frontal Florimont and Réchésy folds of the Ajoie, which also involve the Sundgau Gravels, are associated with compressionally reactivated WSW-ENE striking Permo-Carboniferous basement faults and, thus, are thick skinned (Giamboni et al. 2004b; Ustaszewski et al. 2005). It is unknown whether this also applies to the Banné and Vendlincourt anticlines to the south that may have developed during the Pliocene and Quaternary (Braillard 2006). Further to the east, the thin-skinned frontal Ferrette and Landskron folds, which are associated with the Paleogene Ferrette and Allschwil faults of the URG, respectively, probably began to develop prior to the deposition of the

70 P.A. Ziegler \& M. Fraefel 
Sundgau Gravels (Ustaszewski \& Schmid 2006) and presumably continued to grow during the late Pliocene and Quaternary compressional deformation of the Mulhouse High.

These young anticlines are all characterized by minor wind and/or water gaps (e.g. gaps in the Ferrette anticline at Durlinsdorf and Ferrette; Fig. 2b). Moreover, they are located to the north of the Blauen, Glaserberg and Mont Terri anticlines, which are devoid of wind and water gaps. Thus, development of these gaps must be attributed to rivers that originated in the earlier elevated ranges of the Jura Mountains to the south, and that incised into the evolving frontal anticlines during their Pliocene and Quaternary development (Giamboni et al. 2004b; Braillard 2006).

Regarding the Pliocene and Quaternary evolution of the Franches-Montagnes and the adjacent parts of the FrancheComté, the relatively high sinuosity of the rivers Doubs and Dessoubre indicates that they developed as low gradient rivers prior to their incision by $300-400 \mathrm{~m}$ into the gently undulating relief of this plateau, which apparently was nearly peneplained after its mid-Tortonian to end-Messinian main deformation. The indicated timing of the main deformation of the FranchesMontagnes and the Franche-Comté is compatible with (i) the fact that deformation of the internal Mont d'Amin anticline (Fig. 2a) had ceased by early Pliocene times, as evidenced by a geopetal karst fill dated as MN15 (4.1-3.6 Ma; Bolliger et al. 1993), and (ii) that the Lédonien thrust sheet (Fig. 1) had overridden the eastern margin of the Bresse Graben at the Miocene-Pliocene transition but became inactive thereafter (ca. 5.3 Ma; Chauve et al.1988; Guellec et al. 1990; Roure et al. 1994). Mid-Pliocene to Quaternary (ca. 4-0 Ma) uplift of the Franches-Montagnes and Franche-Comté, causing deep incision of the rivers Doubs and Dessoubre, is attributed to latestage thick-skinned deformation of the Jura Mountains, involving the inversion of Permo-Carboniferous troughs, as indicated by reflection-seismic data and seismic activity (Roure et al. 1994; Philippe et al.1996; Becker 2000; Lacombe \& Mouthereau 2002; Pfiffner 2006; Ustaszewski \& Schmid 2007).

During the Pliocene and Quaternary, compressional deformation continued beyond the Faisceau Bisontin and ultimately also affected the Avant-Monts domain to the NW (Fig. 1; Madritsch et al. 2008). The Clerval water gap through the Ormont anticline (Fig. 2b) speaks for the antecedence of the river Doubs with respect to the development of the Faisceau Bisontin. Growth of the Bisontin bundle of folds, as well as of the Lomont Anticline had confined the deposition of the Sundgau Gravels and their equivalents to the Montbéliard Plateau and Avant-Monts domain (Fig. 7).

\section{Geodetic constraints on neotectonics}

Precision levelling data (Müller et al. 2002) indicate that the thrust belt of the Eastern Jura Mountains currently rises at rates of $0.25-0.35 \mathrm{~mm} / \mathrm{y}$, whilst the Swiss Tabular Jura appears to be stable and the Dinkelberg Block to the north subsides gently with respect to a reference point at Laufenburg. Assum- ing for the Jura thrust belt a basal $30^{\circ}$ ramp, its uplift rate can be translated into ongoing horizontal displacement rates of $0.5-0.7 \mathrm{~mm} / \mathrm{y}$ (Müller et al. 2002). The Swiss GPS Reference Network LV95, however, has not yet detected corresponding horizontal displacements (Brockmann et al. 2005). Furthermore, precision levelling shows that adjacent to the Freiburg embayment the alluvial plain of the URG subsides relative to the Black Forest at rates of $0.5-0.6 \mathrm{~mm} / \mathrm{y}$, with the fault systems of the Freiburg embayment being tectonically and seismically active (Behrmann et al. 2003; Rózsa et al. 2005). Moreover, precision levelling data indicate that the valley-and-ridge province and the Franches-Montagnes gently subside with respect to the Laufenburg reference point, possibly in response to strike-slip reactivation of URG-related basement-involving fault systems that extend beneath these areas (Schlatter et al. 2005). This is compatible with the fault-plane solutions of earthquakes occurring in the area of the Eastern Jura Mountains (Deichmann et al. 2000; Müller et al. 2002). Yet, repeated levelling surveys, carried out during the last 30 years near the city of Basel, have not detected any movements on the Rhine Valley Flexure (Schlatter et al. 2005), even though it has a distinct morphological expression. Considering that the terraces of the Rhine do not give clear evidence for late Quaternary tectonic activity (Wittmann 1961; Haldimann et al. 1984; Verderber 2003), this may mean that either stresses are currently building up on this important fault, or that tectonic deformation is partitioned over a number of faults and thus, is difficult to detect.

GPS data acquired during the last 17 years show only minor differential horizontal displacements for campaign stations located within the JFTB; these are at best close to the level of significance (Brockmann et al.2005) but do not reflect a consistent deformation pattern. On the other hand, data derived from the European network of continuously operating GPS reference stations indicate sinistral transtensional displacement rates of up to $0.76 \mathrm{~mm} / \mathrm{y}$ between the flanks of the URG and similar transpressional to compressional displacement rates across the Bresse-URG transfer zone (Tesauro et al. 2005).

\section{Summary}

Thin-skinned deformation of the JFTB commenced probably around 10-9 Ma during the middle Tortonian and continued during the Pliocene when thick-skinned deformation became increasingly important (Becker 2000; Ustaszewski \& Schmid 2007). During the Tortonian initial deformation pulses the preexisting south-directed consequent drainage system that had developed in response to late Burdigalian (ca.18 Ma) uplift of the Vosges-Black Forest Arch (Fig. 4) was gradually overpowered. With this, development of the modern drainage systems of the JFTB and its fore- and hinterlands commenced, as outlined below:

1) During the initial deformation stage of the JFTB, spanning approximately middle and late Tortonian times (107.2 Ma), the deformation front propagated NW-ward across 
the Franches-Montagnes into the upper reaches of the river Doubs and across the Delémont Basin to the Les Vorbourgs, Movelier and Thierstein anticlines, but probably not much beyond the Langenbruck area into the eastern thrust belt (Figs. 2 and 5). During this stage, development of major water and wind gaps commenced in the valley-and-ridge province, owing to incision of the S-directed consequent Jura Nagelfluh drainage system into the rising anticlines. As folding progressed, this drainage system was gradually overpowered and new subsequent drainage systems developed, which were linked by resequently and obsequently employed segments of the antecedent Jura Nagelfluh river system, thus accounting for further incision of major water gaps. Contemporaneous uplift, ENE-ward tilting and erosion of the Swiss Molasse Basin in response to thin-skinned shortening in the JFTB, controlled the abandonment of the WSW-directed Glimmersand drainage system and the gradual development of an ENE-directed precursor of the Aare-Danube drainage system.

2) During the second stage, spanning approximately Messinian and early Pliocene times (7.2-4.2 Ma), the deformation front of the JFTB propagated into the Franche-Comté and Sundgau, activating the Lomont, Mt. Terri, Bueberg, Glaserberg and Blauen anticlines, as well as into the eastern thrust belt (Figs. $2 \&$ 6). During this stage, the combined subsequent and resequent Suze and Dünnern drainage systems of the internal Jura Mountains debouched S-ward via water gaps into the ENE-ward flowing river Aare-Danube (Fig. 3). By this time, the Aare-Danube and its tributary rivers Reuss and Limmat had cut water gaps through the rising Born, Chestenberg and Lägern anticlines. On the other hand, the combined subsequent and obsequent Birs drainage system of the valley-and-ridge province flowed $\mathrm{N}$ ward, cutting the Laufen and Angenstein gaps, and joined the consequent Black Forest rivers at the southern end of the URG, thus forming the headwaters of the evolving SWward flowing proto-Doubs river. Moreover, the combined subsequent and obsequent upper reaches of the river Doubs probably developed during this stage, employing water gaps that initially were carved through evolving anticlines by the S-ward flowing river Savoureuse.

3) The third stage in the evolution of the Jura Mountain drainage systems commenced with the late early Pliocene (4.2 Ma) capture of the river Aare by the proto-Doubs drainage system at the eastern end of the JFTB. As evidenced by the Sundgau and Desnes Gravels (4.2-2.9 Ma), this new AareDoubs flowed in the foreland of the Jura Mountains SWward into the tensionally subsiding Bresse Graben where it found its erosional base level (Fig. 7). During the deposition of the Sundgau Gravels shortening persisted in the eastern Jura thrust belt and in front of the valley-and-ridge province, where the thin-skinned Landskron and Ferrette anticlines, as well as the Vendlincourt and Banné anticlines continued to grow. These evolving structures were transected by $\mathrm{N}$ ward flowing rivers, which originated on the flanks of ear- lier-formed anticlinal ridges of the Jura Mountains to the south, thus causing the development of water/wind gaps. At the same time the deformation front advanced further into the Franche-Comté and uplift of the Franches-Montagnes and Franche-Comté commenced, controlling incision of the meandering rivers Doubs and Dessoubre.

4) The fourth stage in the evolution of the Jura Mountain drainage systems commenced in the late Pliocene (2.9 Ma) with the deflection of the river Aare into the URG, the southern parts of which resumed subsiding in a transtensional stress regime. This provided the combined Aare-Rhine with a new erosional base level (Fig. 8). Continued subsidence of the URG caused incision of the river Aare and its tributaries in the Jura Mountains and in the gently rising Black Forest upstream from Basel. During the late Pliocene and early Quaternary (2.9-1.7 Ma), shortening persisted in the JFTB, as evidenced in the Sundgau and Ajoie by folding of the Sundgau Gravels, that was controlled by dextral transpressional reactivation of ENE striking Permo-Carboniferous basement faults (Florimont and Réchésy anticlines) and by sinistral reactivation of SSW trending URG-related basement faults (Mulhouse High) (Ustaszewski \& Schmid 2006, 2007).

5) The final, Quaternary (1.7-0 Ma) evolutionary stage of the Jura Mountain drainage systems was dominated by continued subsidence of the URG, involving further lowering of the erosional base level of the river Aare-Rhine. The latter captured the Alpine headwaters of the river Rhine in the area of Lake Constance around 1.7 Ma, and the FeldbergDanube on the eastern flank of the Black Forest around 19-20 ka (Fig. 9). With this the water and sediment load of the newly formed Alpine Rhine increased significantly. Continued compressional deformation of the JFTB, though at low strain rates, is evidenced by (1) the development of the thin-skinned Mandach and Mettau thrusts in the eastern parts of the Tabular Jura sometime after 1.6 Ma, (2) further deformation of the Mulhouse High, and (3) changes in the drainage pattern of the Sundgau and Ajoie - controlled by both structure and headward erosion - that had repercussions on the location of the watersheds between the rivers Rhine, Ill and Doubs.

Present-day tectonic activity in the domain of the Jura Mountains is evidenced by their seismic record and geodetic measurements. Seismicity testifies to on-going reactivation of pre-existing crustal discontinuities under the prevailing NWdirected compressional stress field (Becker2000; Deichmann et al. 2000; Müller et al. 2002; Lacombe \& Mouthereau2002). Repeated precision levelling, covering time spans of 25 to 60 years, indicates that the thrust belt of the Eastern Jura Mountains is currently being uplifted at rates of $0.25-0.35 \mathrm{~mm} / \mathrm{y}$, the valley-and-ridge province and the Franches-Montagnes subside gently, while the alluvial plain of the URG subsides at rates of $0.5-0.6 \mathrm{~mm} / \mathrm{y}$ and the Black Forest is apparently relatively stable with respect to a reference point at Laufenburg. In the

72 P.A. Ziegler \& M. Fraefel 
Eastern JFTB no appreciable shortening can be deduced from GPS data, which cover a time span of 17 years (Müller et al. 2002; Schlatter et al. 2005; Brockmann et al. 2005).

\section{Conclusions}

We distinguish five stages in the development of the modern drainage systems of the Jura Mountains, taking into account the distribution of water/wind gaps, which we consider as evidence of former river courses. These stages are intimately related to the evolution of the JFTB and the URG. The timing and scope of the underlying deformation stages of the JFTB are, however, poorly constrained, owing to the general lack of a syndeformational sedimentary record within the Jura Mountains and to the limitation of stratigraphic controls in their foreland to Mid-Pliocene and younger times. Consequently, the timing of the five evolutionary stages of the Jura Mountain drainage systems, as summarized above, must be considered as tentative. In this respect, special attention has to be paid to the Pliocene and Quaternary deformation of the Jura Mountains and their surroundings.

Compared to the thin-skinned deformation of the JFTB that had commenced around 9-10 Ma, its thick-skinned transpressional to strike-slip deformation apparently played an increasingly important role from about $3 \mathrm{Ma}$ onward, controlling folding of the Sundgau Gravel. This is evidenced by reflectionseismic data (Ustaszewski \& Schmid 2006), seismicity and geomorphologic features indicating late-stage broad uplift of the Franches-Montagnes and Franche-Comté that controlled deep incision of the rivers Doubs and Dessoubre. This PlioceneQuaternary phase of thick-skinned deformation of the JFTB, which involved reactivation of ENE striking Permo-Carboniferous troughs and fault systems (Roure et al. 1994; Philippe et al. 1996; Ustaszewski \& Schmid 2007; Madritsch et al. 2008), reflects an increase in the magnitude of NW-directed compressional intraplate stresses in the Alpine foreland. From about 2.9 Ma onward, these stresses governed the renewed transtensional subsidence of the southern parts of the URG, continued subsidence of its northern parts (Dèzes et al. 2004) and probably also moderate uplift of the seismically still active VosgesBlack Forest Arch (Edel et al. 2006). Beyond the area of the URG, these stresses controlled the late Pliocene-early Quaternary accelerated tensional subsidence of the Lower Rhine Graben, and by lithospheric folding, accelerated subsidence of the North Sea-North German Basin (for refs. see Dèzes et al. 2004; Ziegler \& Dèzes 2007).

In the Tabular Jura, the $3-4^{\circ}$ southern dip of the Jura Nagelfluh (Diebold et al. 2006) reflects gentle post-early Tortonian uplift of the Black Forest. Late-stage uplift of the Black Forest Arch is furthermore supported by the occurrence of gravels attributed to the Messinian to early Pliocene Aare-Danube at $600 \mathrm{~m}$ above MSL in the lower Aare valley (Geissberg), and downstream at $900 \mathrm{~m}$ above MSL on the eastern flank of the Black Forest (Eichberg near Blumberg) (Fig. 6; Hofmann 1996; Müller et al. 2002). It is, however, uncertain whether this late- stage uplift of the Black Forest contributed to the westward deflection of the river Aare from its previous easterly course around 4.2 Ma, as postulated by Hofmann (1996), or whether it post-dates this drainage system reorganization.

Present-day seismicity seems to concentrate on fault systems that extend SSW-ward from the URG and to ENE trending fault systems that outline Permo-Carboniferous troughs (Ustaszewski 2004, Ustaszewski et al. 2005; Ustaszewski \& Schmid 2007). Late Pliocene to present-day thick-skinned deformation of the Jura Mountains probably involves the activation of an intra-crustal detachment horizon that extends from the Alps beneath the Molasse Basin into the Jura domain (Mosar 1999; Lacombe \& Mouthereau 2002; Pfiffner 2006; Edel et al. 2006; Ustaszewski \& Schmid 2007). The geodetic record, combined with geomorphologic evidence, indicates that the Eastern JFTB, which has accounted for up to $30 \mathrm{~km}$ of thinskinned shortening in its western parts during the last 9-10 million years (Philippe et al. 1996; Affolter \& Gratier 2004), is currently tectonically still active but deforms at very low horizontal displacement rates of less than $1 \mathrm{~mm} / \mathrm{y}$.

\section{Acknowledgements}

This paper is a contribution to the transnational EUCOR-URGENT Project (upper $\underline{R}$ hine Graben, Evolution and Neotectonics) that provided this study with a welcome platform for lively discussions with numerous colleagues. Thanks are herewith extended to all of them and particularly to the members of the Basel EUCOR-URGENT team, which includes H. Madritsch, S. Kock and P. Dèzes. Special thanks go to J-P. Berger, A. Densmore, J. Kuhlemann, S.M. Schmid, K. Ustaszewski and E. Villinger for critical and constructive comments on a draft of this paper. M. Fraefel acknowledges financial support by the Swiss Science Agency via a University of Basel ELTEM grant.

\section{REFERENCES}

Affolter,T., Gratier, J.-P. 2004: Map view retrodeformation of an arcuate fold-and-thrust belt: The Jura case. Journal of Geophysical Research 109, B03404, doi:10.1029/2002JB002270.

Bartz, J. 1974: Die Mächtigkeit des Quartärs im Oberrheingraben. In: Illies, H.J., Fuchs, K. (eds.) Approaches to Taphrogenesis. Schweizerbart Stuttgart, Inter-Union-Commission on Geodynamics, Scientific Report 8, 78-87.

Becker, A. 2000: The Jura Mountains - an active foreland fold-and-thrust belt? Tectonophysics 321, 381-406.

Behrmann, J.H., Hermann, O., Horstmann, M., Tanner, D.C., Bertrand, G. 2003: Anatomy and kinematics of oblique continental rifting revealed: a three-dimensional case study of the southern Upper Rhine Graben (Germany). American Association of Petroleum Geologists, Bulletin 87, 1105-1121.

Berger, J.-P., Reichenbacher, B., Becker, D., Grimm, M., Grimm, K., Picot, L., Storni, A., Pirkenseer, C., Derer, C., Schäfer, A. 2005a: Paleogeography of the Upper Rhine Graben (URG) and the Swiss Molasse Basin (SMB) from Eocene to Pliocene. International Journal of Earth Sciences 94/4, 697-710.

Berger, J.-P., Reichenbacher, B., Becker, D., Grimm, M., Grimm, K., Picot, L., Storni, A., Pirkenseer, C., Schäfer, A. 2005b: Eocene-Pliocene time scale and stratigraphy of the Upper Rhine Graben (URG) and the Swiss Molasse Basin (SMB). International Journal of Earth Sciences 94/4, 711731.

Bieg, U. 2005: Palaeooceanographic modelling in global and regional scale: An example from the Burdigalian Seaway Upper Marine Molasse (Early Miocene). Ph.D. Thesis, University Tübingen, 118 pp. 
Bitterli,T., Matousek, F. 1991: Tektonik des östlichen Aargauer Tafeljuras Mitteilungen der Aargauischen Naturforschenden Gesellschaft XXXIII, 5-30.

Bolliger, T., Engesser, B., Weidmann, M. 1993: Première découverte de mammifères pliocènes dans le Jura neuchâtelois. Eclogae Geologicae Helvetiae 89,1043-1048.

Braillard, L. 2006: Morphogenèse des vallées sèches du Jura tabulaire d'Ajoie (Suisse): rôle de la fracturation et étude des remplissages quaternaires. $\mathrm{Ph}$. D. Thesis, University Fribourg. GeoFocus 14, 224 pp.

Brockmann, E., Ineichen, D. and Wiget, A. 2005. Neumessung und Auswertung des GPS-Landesnetzes der Schweiz LV95. Geomatik Schweiz 08/05: 440-444.

Burkhard, M., Sommaruga, A. 1998: Evolution of the western Swiss Molasse basin: Structural relations with the Alps and the Jura belt. In: A. Mascle, C. Puigdefàbregas, H.P. Luterbacher, M. Fernandez (eds.), Cenozoic Foreland Basins of Western Europe. Geological Society, London, Special Publications 134, 279-298.

Carretier, S., Nivière, B., Giamboni, M., Winter T. 2006: Do river profiles record along-stream variations of low uplift rate? Journal of Geophysical Research 111, F02024, doi:10.1029/2005JF00041.

Chauve, P., Enay, R., Fluck, P., Sittler, C. 1980: L'Est da la France (Vosges, Fossé Rhénan, Bresse, Jura). Annales scientifiques Université de Besançon, Géologie, 4ème série, fasc 1, 3-80.

Chauve, P., Martin, J., Petitjean, E., Sequeiros, F. 1988: Le chevauchement du Jura sur la Bresse. Données nouvelles et réinterpretation des sondages. Bulletin de la Société Géologique de France 8 (IV), 861-870.

Deichmann, N., Ballarin Dolfin, D., Kastrup, U.: 2000: Seismizität der Nordund Zentralschweiz. Nagra Technischer Bericht, Wettingen, NTB 00-05, $93 \mathrm{pp}$.

Dèzes, P., Schmid, S.M., Ziegler, P.A. 2004: Evolution of the Cenozoic Rift System: interaction of the Alpine and Pyrenean orogens with their foreland lithosphere. Tectonophysics 389, 1-33.

Deville, E., Blanc, E., Tardy, M., Beck, C., Cousin, M., Ménard, G. 1994: Thrust propagation and syntectonic sedimentation in the Savoy Tertiary Molasse Basin (Alpine Foreland). In: A. Mascle (ed.) Hydrocarbon and Petroleum Geology of France. European Association of Petroleum Geoscientists Special Publication 4, 269-280.

Diebold, P., Bitterli-Brunner, P., Naef, H. 2006: Blatt 1069/1049 FrickLaufenburg. - Geologischer Atlas der Schweiz 1:25'000, Erläuterungen, $110 \mathrm{pp}$.

Edel, J-B., Whitechurch, H., Diraison, M. 2006: Seismicity wedge beneath the Upper Rhine Graben due to backwards Alpine push? Tectonophysics 428, 49-64.

Fejfar, O., Heinrich, W.-D., Lindsay, E.H. 1998: Updating the Neogene rodent biochronology. Meddelingen Nederlands Instituut voor Toegepaste Geowetenschappen TNO 60, 533-554.

Fromm, K. 1989. Paläomagnetische Untersuchungen zur Quartärstratigraphie im Südschwarzwald bei Schadenbirndorf. Geowissenschaftliche Gemeinschaftsaufgaben, Niedersächsisches Landesamt für Bodenforschung, Hannover, 16 pp.

Fügenschuh, B., Schmid, S.M. 2003: Late stage of deformation and exhumation of an orogen constrained by fission-track data: a case study in the Western Alps. Geological Society of America, Bulletin 115, 1425-1440.

Giamboni, M., Wetzel, A., Nivière, B., Schumacher, M. 2004a: Plio-Pleistocene folding in the southern Rhinegraben recorded by the evolution of the drainage network (Sundgau area; northwestern Switzerland and France). Eclogae Geologicae Helvetiae 97/1, 17-31.

Giamboni, M., Ustaszewski, K., Schmid, S.M., Schumacher, M., Wetzel, A. 2004b: Plio-Pleistocene reactivation of Paleozoic and Paleogene structures in the Rhine-Bresse transform zone (northern Switzerland and eastern France). International Journal of Earth Sciences 93/2, 207-223.

Guellec, S., Mugnier, J.-L., Tardy, M., Roure, F. 1990: Neogene evolution of the western Alpine foreland in the light of the ECORS data and balanced cross-section. Société Géologique de France Mémoire 156, $165-184$.

Hagedorn, E.-M. 2004. Sedimentpetrographie und Lithofazies der jungtertiären und quartären Sedimente im Oberrheingebiet. Ph.D. Thesis, University of Cologne.
Hagedorn, E.-M., Boenigk, W. 2008: The Pliocene and Quaternary sedimentary and fluvial history in the Upper Rhine Graben based on heavy mineral analyses. Netherlands Journal of Geosciences 87/1,21-32.

Haimberger, R., Hoppe, A., Schäfer A. 2005: High-resolution seismic survey on the Rhine River in the northern Upper Rhine Graben. International Journal of Earth Sciences 94/4, 657-668.

Haldimann, P., Naef, H., Schmassmann, H. 1984: Fluviatile Erosions- und Akkumulationsformen als Indizien jungpleistozäner und holozäner Bewegungen in der Nordschweiz und angrenzenden Gebieten. Nagra Technischer Bericht, Wettingen, NTB 84-19,112 pp.

Heim, A. 1919: Geologie der Schweiz, Band 1, Molasseland und Juragebirge. Chr. Herm. Tauchnitz, Leipzig, 704 pp.

Hinsken, S., Ustaszewski, K., Wetzel, W. 2007: Graben width controlling synrift sedimentation: The Paleogene southern Upper Rhine Graben as an example. International Journal of Earth Sciences 96/6, 979-1002.

Hofmann, F. 1960: Beitrag zur Kenntnis der Glimmersandsedimentation in der oberen Süswassermolasse der Nord- und Nordostschweiz. Eclogae Geologicae Helvetiae 53/1,1-25.

Hofmann, F. 1969: Neue Befunde über die westliche Fortsetzung des beckenaxialen Glimmersand-Stromsystems in der Oberen Süsswassermolasse des schweizerischen Alpenvorlandes. Eclogae Geologicae Helvetiae 62/1, $279-284$.

Hofmann, F. 1996: Zur plio-pleistozänen Landschaftsgeschichte im Gebiet Hochrhein-Wutach-Randen-Donau: Geomorphologische Ueberlegungen und sedimentpetrographische Befunde. Eclogae Geologicae Helvetiae 89/3,1023-1041.

Kälin, D. 1997: Litho- und Biostratigraphie der mittel- bis obermiozänen Bois de Raube-Formation (Nordwestschweiz). Eclogae Geologicae Helvetiae 90/1, 97-114.

Kemna, H.A. 2008: A revised stratigraphy for the Pliocene and Lower Pleistocene deposits of the Lower Rhine Embayment. Netherlands Journal of Geosciences 87/1,91-105.

Kemna, H.A., Becker-Haumann, R. 2003: Die Wanderblock-Bildung im Schweizer Juragebirge südlich von Basel: Neue Daten zu einem alten Problem. Eclogae Geologicae Helvetiae 96/1,71-83.

Kempf, O., Matter, A., Burbank, D.W., Mange, M. 1999: Depositional and structural evolution of a foreland basin margin in a magnetostratigraphic framework: the eastern Swiss Molasse Basin. International Journal of Earth Sciences 88/2, 253-275.

Kuhlemann J., Kempf, O. 2002: Post-Eocene evolution of the North Alpine Foreland Basin and its response to Alpine tectonics. Sedimentary Geology $152,45-78$.

Lacombe, O., Mouthereau,F. 2002: Basement-involving shortening and deep detachment tectonics in the forelands of orogen: Insights from recent collision belts (Taiwan, Western Alps, Pyrenees), Tectonics 21, 10.1029/2001TC901018.

Lang, U., Gudera, T., Elsass, P., Wirsing, G. 2005: Numerical modelling of chloride propagation in the quaternary aquifer of the southern Upper Rhine Graben. International Journal of Earth Sciences 94/4, 550-564.

Laubscher, H.P. 1961: Die Fernschubhypothese der Jurafaltung. Eclogae Geologicae Helvetiae 54, 221-282.

Laubscher, H.P. 1967: Exkursion Nr. 14, Basel-Delémont-Biel. Geologischer Führer der Schweiz, Heft 4, 217-237.

Laubscher, H.P. 1981: The 3D propagation of décollement in the Jura. In: K.R. McClay and N.J. Price (eds.) Thrust and Nappe Tectonics. Geological Society, London, Special Publications 9, 311-318.

Laubscher, H.P. 1986: The eastern Jura: relations between thin-skinned and basement tectonics, local and regional. Geologische Rundschau 75, 535553.

Laubscher, H. 1992. Jura kinematics and the Molasse Basin. Eclogae Geologicae Helvetiae 85/3, 653-675.

Laubscher, H. 1998: Der Ostrand des Laufenbeckens und der Knoten von Grellingen: Die verwickelte Begegnung von Rheingraben und Jura. Eclogae Geologicae Helvetiae 91/2, 275-291.

Laubscher, H. 2001: Plate interactions at the southern end of the Rhine graben. Tectonophysics 343,1-18.

Laubscher, H. 2003: The Miocene dislocations in the northern foreland of the Alps: oblique subduction and its consequences (Basel area, Switzerland-

74 P.A. Ziegler \& M. Fraefel 
Germany). Jahresberichte und Mitteilungen des Oberrheinischen Geologischen Vereins, Neue Folge 85, 423-439.

Le Carlier de Veslud, C., Bourgeois, O., Diraison, M., Ford, M. 2005: 3D stratigraphic and structural synthesis of the Dannemarie basin (Upper Rhine Graben). Bulletin de la Société Géologique de France 176, 433-442.

Liniger, H. 1953: Zur Geschichte und Geomorphologie des nordschweizerischen Juragebirges. Geographica Helvetica 8, 289-303.

Liniger H. 1966: Das Plio-Altpleistozäne Flussnetz der Nordschweiz. Regio Basiliensis 7, 158-177.

Liniger, H. 1967: Pliozän und Tektonik des Juragebirges. Eclogae Geologicae Helvetiae 60/2, 407-490.

Lopes Cardozo, G.G.O., Behrmann J.H. 2006: Kinematic analysis of the Upper Rhine Graben boundary fault system. Journal of Structural Geology 28, 1028-1039.

Madritsch, H., Schmid, S.M., Fabbri, O. 2008: Interactions of thin- and thickskinned tectonics along the northwestern front of the Jura fold-andthrust-belt (Eastern France). Tectonics (in press).

Müller, W.H., Naef, H., Graf, H.R. 2002: Geologische Entwicklung der Nordwestschweiz, Neotektonik und Langzeitszenarien Zürcher Weinland. Nagra Technischer Bericht, Wettingen, NTB 99-08, 237 pp.

Mosar, J. 1999: Present-day and future tectonic underplating in the western Swiss Alps: reconciliation of basement/wrench-faulting and décollement folding of the Jura and Molasse basin in the Alpine foreland. Earth and Planetary Science Letters 173, 143-155.

Nivière, B., Winter, T. 2000: Pleistocene northward fold propagation of the Jura within the southern Upper Rhine Graben: seismotectonic implications. Global and Planetary Change 27, 263-288.

Petit, C., Campy, M., Chaline, J., Bonvalot, J. 1996: Major palaeohydrographic changes in Alpine foreland during the Pliocene-Pleistocene. Boreas 25, 341-143.

Pfiffner, O.A. 2006: Thick-skinned and thin-skinned styles of continental contraction. Geological Society of America, Special Paper 414, 153-177.

Philippe, Y., Colletta, B., Deville. E., Mascle, A. 1996: The Jura fold-andthrust belt: a kinematic model based on map-balancing. In: Ziegler, P. A, Horvàth, F. (eds.), Peri-Tethys Memoir 2: Structure and prospects of Alpine basins and forelands. Mémoires du Muséum national d'Histoire naturelle, Paris 170, 235-261.

Rahn, M.K., Selbekk, R. 2007: Absolute dating of the youngest sediments of the Swiss Molasse basin by apatite fission track analysis. Swiss Journal of Geosciences 100,371-381.

Rolf, C., Hambach, U., Weidenfeller, M. 2008: Rock and palaeomagnetic evidence for the Plio-Pleistocene palaeoclimatic change recorded in the Upper Rhine Graben sediments (core Ludwigshafen-Parkinsel). Netherlands Journal of Geosciences 87/1, 41-50.

Rotstein, Y., Behrmann, J.H., Lutz, M., Wirsing, G., Lutz, A. 2005a: Tectonic implications of transpression and transtension: Upper Rhine Graben. Tectonics 24, doi:10.1029/2005TC111797.

Rotstein, Y., Schaming, M., Rousse, S. 2005b: Structure and Tertiary tectonic history of the Mulhouse High, Upper Rhine Graben: block faulting modified by changes in the Alpine stress regime. Tectonics 24, TC1012. doi:10.1029/2004TC001654.

Roure, F., Brun, J.-P., Colletta, B., Vially, R. 1994: Multiphase extensional structures, fault reactivation, and petroleum plays in the Alpine foreland Basin of southeastern France. In: Mascle, A (ed.), Hydrocarbon and Petroleum Geology of France. Springer-Verlag Berlin Heidelberg New York, European Association of Petroleum Geoscientists, Special Publication 4, 245-268.

Rózsa, Sz., Heck, B., Mayer, M., Seitz, K., Westerhaus, M., Zippelt, K. 2005: Determination of displacements in the upper Rhine graben Area from GPS and levelling data. International Journal of Earth Sciences 94/4, 538-549.

Schlatter, A., Schneider, D., Geiger,A., Kahle,H.-G. 2005: Recent vertical movements from precise levelling in the vicinity of the city of Basel, Switzerland. International Journal of Earth Sciences 94/4, 507-514.
Schreiner, A. 1965: Die Juranagelfluh im Hegau. Jahresheft Geologisches Landesamt Baden-Württemberg 7, 303-354.

Simpson, G. 2004a: Role of river incision in enhancing deformation. Geology 32/4, 341-344.

Simpson, G. 2004b: A dynamic model to investigate coupling between erosion, deposition and three-dimensional (thin-plate) deformation. Journal of Geophysical Research 109, F02006, doi:10.1029/2003JF000078.

Sissingh, W. 2006: Syn-kinematic palaeogeographic evolution of the West European Platform: correlation with the Alpine plate collision and foreland deformation. Netherlands Journal of Geosciences 85, 131-180.

Skinner, B.J., Porter, S.C. 1995: The Dynamic Earth: an introduction to Physical Geology. 3d. Ed. John Wiley \& Sons, New York.

Tesauro, M., Hollenstein, C., Egli, R., Geiger, A., Kahle, H.-G. 2005: Continuous GPS and broad-scale deformation across the Rhine Graben and the Alps. International Journal of Earth Sciences 94/4, 525-537.

Twidale, C.R. 2004: River patterns and their meaning. Earth-Science Reviews 67/3-4, 159-219.

Ustaszewski, K.M. 2004: Reactivation of pre-existing crustal discontinuities: the southern Upper Rhine Graben and the northern Jura Mountains - a natural laboratory. Ph.D. Thesis, University Basel.

Ustaszewski, K., Schmid, S.M. 2006: Control of preexisting faults on geometry and kinematics in the northernmost part of the Jura fold-and-thrust belt. Tectonics 25, TC5003, doi:10.1029/2005TC0011915.

Ustaszewski, K., Schmid, S.M. 2007: Latest Pliocene to recent thick-skinned tectonics at the Upper Rhine Graben - Jura Mountains junction. Eclogae Geologicae Helvetiae, Swiss Journal of Geosciences 100, 293-312.

Ustaszewski, K., Schumacher, M.E., Schmid, S.M., Nieuwland, D. 2005: Fault reactivation in brittle-viscous wrench systems - dynamically scaled analogue models and application to the Rhine-Bresse transfer zone. Quaternary Science Reviews 24, 363-380.

Verderber, R. 1992: Quartärgeologische Untersuchungen im Hochrheingebiet zwischen Schaffhausen und Basel. Ph.D. Thesis, University of Freiburg $169 \mathrm{pp}$.

Verderber, R. 2003: Quartärgeologie im Hochrheingebiet zwischen Schaffhausen und Basel. Zeitschrift der deutschen geologischen Gesellschaft 154, 369-406.

Villinger, E. 1998: Zur Flussgeschichte von Rhein und Donau in Südwestdeutschland. Jahresberichte und Mitteilungen des Oberrheinischen Geologischen Vereins, Neue Folge 80,361-398.

Villinger, E. 1999: Freiburg im Breisgau - Geologie und Stadtgeschichte. Landesamt für Geologie, Rohstoffe und Bergbau. Informationen 12, 60 pp.

Villinger, E. 2003: Zur Paläogeographie von Alpenrhein und oberer Donau. Zeitschrift der deutschen geologischen Gesellschaft 154, 193-253.

Westerhoff, W.E., Kemna, H.A., Boenigk, W. 2008. The confluence area of Rhine, Meuse, and Belgian rivers: Late Pliocene and Early Pleistocene fluvial history of the northern Lower Rhine Embayment. Netherlands Journal of Geosciences 87/1,107-125.

Wittmann, O. 1961: Die Niederterrassenfelder im Umkreis von Basel und ihre kartographische Darstellung. Basler Beiträge zur Geographie und Ethnologie 3, 46 pp.

Ziegler, P.A., Dèzes, P. 2007: Cenozoic uplift of Variscan Massifs in the Alpine foreland: Timing and controlling mechanisms. Global and Planetary Change 58, 237-269.

Ziegler, P. A., Bertotti, G., Cloetingh, S. 2002. Dynamic processes controlling foreland development - the role of mechanical (de)coupling of orogenic wedges and forelands. In: Bertotti, G., Schulmann, K. \& Cloetingh, S. (eds) Continental Collision and the Tectono-Sedimentary Evolution of Forelands. European Geosciences Union, Stephan Mueller Special Publication Series 1, 17-56.

Manuscript received March 3, 2008

Revision accepted January 1,2009

Published Online first March 28, 2009

Editorial Handling: Joachim Kuhlemann \& Stefan Bucher 